\title{
Historycznie stosowane impregnaty do wzmacniania zniszczonego drewna polichromowanego - próba przeglądu. Część II: Impregnaty syntetyczne
}

\section{Wprowadzenie}

Metody i środki stosowane w zabiegach impregnacji wzmacniającej drewnianych zabytkowych obiektów polichromowanych sa jednymi z najważniejszych czynników warunkujących ich skuteczność.

Każdorazowo typując najodpowiedniejsze, mamy obowiązek dokonania wyboru zgodnie z postępująca na ten temat wiedzą ${ }^{1}$. Tak czynimy my, tak też postępowali nasi poprzednicy. Materiały użyte przed laty dzisiaj częstokroć oceniane są krytycznie. Stały się jednak nierozłączną częścią obiektów,

1 B. Chmielewski, Uwagi do „Kodeksu etyki zawodowej konserwatorón dziet sztuki”, „Biuletyn Informacyjny Konserwatorów Dzieł Sztuki” 1998, nr 4, s. 21; E.C.C.O. Europejska Konfederacja Zwiazkón Konserwatorów Dzieł Sz̨uki, „Biuletyn Informacyjny Konserwatorów Dzieł Sztuki" 1998, nr 4, s. 25; J. Furdyna, Wybór wartości i inne zagadnienia teoretyczne w konserwacji dziet s₹̨tuki, „Biuletyn Informacyjny Konserwatorów Dzieł Sztuki” 1998, nr 4, s. 13; B. Rouba, Potrzeba rozszerzenia Kodeksu Etyki Zawodowej, „Biuletyn Informacyjny Konserwatorów Dzieł Sztuki” 1998, nr 4, s. 33; eadem, Zasady postępowanie etycznego w ochronie dóbr kultury, „Biuletyn Informacyjny Konserwatorów Dzieł Sztuki” 2000, nr 2, s. 84, 87; J. Wolski, Kodeks etyki zawodowej konserwatorón džiet sžtuki, „Biuletyn Informacyjny Konserwatorów Dzieł Sztuki" 1998, nr 4, s. 16; idem, Kodeks etyki zawodowej konserwatorón-restauratorów dziet sz̨tuki, „Biuletyn Informacyjny Konserwatorów Dzieł Sztuki” 2000, nr 2, s. 91. 
które coraz częściej są przedmiotem kolejnych ingerencji konserwatorskich. Próba przeglądu impregnatów wydaje się więc znajdować uzasadnienie.

Materiały syntetyczne na przestrzeni XX wieku prawie całkowicie zastapiły w impregnacji te pochodzenia naturalnego. Moga one być stosowane w różnych kombinacjach i roztworach, maja większą penetrację, a czas ich utwardzania i lepkość mogą być w różny sposób modyfikowane, w zależności od dodawanych plastyfikatorów, utwardzaczy czy katalizatorów. Przewyższaja one żywice naturalne odpornością na działanie światła i wilgoci oraz grzybów, bakterii czy owadów. Cechuje je wysoka wytrzymałość mechaniczna².

Utwardzenie drewna uzyskuje się przy zastosowaniu żywic syntetycznych spolimeryzowanych w postaci roztworów w rozpuszczalnikach organicznych albo poprzez polimeryzację chemiczna, termiczną lub radiacyjna monomerów w drewnie ${ }^{3}$.

\section{Parafina i wosk mikrokrystaliczny}

Parafina i wosk mikrokrystaliczny używane są jako materiały zastępujące wosk naturalny ${ }^{4}$. W. Ślesiński metodę impregnacji z zastosowaniem parafiny

2 M. Czajnik, Konserwacja drewna zabytkowego w polskich parkach etnograficznych, „Ogólnopolska Konferencja Muzeów i Parków Etnograficznych", Opole 22-24 IX 1970 rok, Opole 1971, s. 131; W. Domasłowski, Konserwacja (wrmacnianie, utwardzanie) drewna pod zmniejszonym ciśnieniem, „Zagadnienia konserwacji drewna, Biblioteka Muzealnictwa i Ochrony Zabytków”, ser. B, t. 3, Warszawa 1961, s. 54; D. E. Olczak, „Metody i środki konserwacji polichromowanych rzeźb drewnianych oraz ich zastosowanie w Zakładzie Konserwacji Malarstwa i Rzeźby Polichromowanej UMK w Toruniu", Praca magisterska napisana w Zakładzie Konserwacji Malarstwa i Rzeźby Polichromowanej Instytutu Zabytkoznawstwa i Konserwatorstwa UMK w Toruniu pod kierunkiem doc. dr hab. Marii Roznerskiej, Toruń 1985, s. 52 (mps przechowywany w bibliotece ZKMiRP, nr 115).

3 P. Buksalewicz, M. Gajdziński, K. Lutomski, W żmacnianie drewna zabytkowego pray uìyciu preparatón Petrifo i Paraloid, [w:] Zabytkowe drewno konserwacja i badania, Warszawa 1987, s. 108; J Bursze, Podtoża drewniane w malarstwie sұtalugonym, Warszawa 1974, s. 22; W. Ślesiński, Konserwacja zabytkón sżuki, t. 1: Malarstwo sztalugowe i ścienne, Warszawa 1989, s. 23; idem, Konserwacja zabytków sæztuki, t. 2: Ržeźba, Warszawa 1990, s. 21; J. Ważny, Stan i perspektyny konserwacii drewna zabytkowego, „Ochrona Zabytków” 1991, nr 2, s. 82.

4 Wosk mikrokrystaliczny jest półsyntetycznym produktem ubocznym powstającym przy rafinacji ropy naftowej. Parafina jest mieszaniną stałych węglowodorów nasyconych, w której skład wchodzą głównie węglowodory o łańcuchu prostym, zawierające od 16 do 48 ato- 
uznaje za wariant impregnacji woskowej. Przeprowadza się ją w kapieli, w roztopionej parafinie o temperaturze $100-110^{\circ} \mathrm{C}$ lub w mieszaninie parafiny i wosku w stosunku 9:1. Rezultaty autor ten określa jako niezadawalające z powodu niedużej penetracji, zwraca też uwagę na możliwość rozklejania się, w wyniku działania wysokiej temperatury, wcześniejszych łączeń spoiwem glutynowym ${ }^{5}$. J. Lehmann opisuje stosowana do obiektów etnograficznych w Muzeum Narodowym w Poznaniu, na przełomie lat pięćdziesiątych i sześćdziesiątych, impregnację przez imersję w mieszaninie wosku, parafiny i kalafonii, przeprowadzaną w ogrzewanych zbiornikach w temperaturze od 75 do $105^{\circ} \mathrm{C}$. Jej wyniki określa jako zachęcajacce, a utwardzenie drewna jako znaczne ${ }^{6}$. Badania porównawcze nad zastosowaniem do impregnacji parafiny w mieszaninie z kalafonią wtapianych na goraco oraz wprowadzanych w roztworze omawia S. M. Nakhla. Jako rozpuszczalnik poleca trójchloroetylen, a uzyskane wyniki ocenia pozytywnie ${ }^{7}$. O próbach zastosowania wosku mikrokrystalicznego do impregnacji rzeźb wspomina również E. Packard ${ }^{8}$. J. Bursze w swej pracy o podłożach drewnianych w malarstwie sztalugowym wymienia go wśród impregnatów?

mów węgla w cząsteczce. Otrzymuje się ją z ropy naftowej po oddestylowaniu olejów smarowych, ze smoły węgla brunatnego, ze smoły łupkowej, torfu lub syntetycznie. Jest to przezroczysta masa, bez zapachu i smaku. Temperatura topnienia parafiny, w zależności od stopnia destylacji, zawiera się w granicach między 35 a $65^{\circ} \mathrm{C}$, gęstość wynosi $0,85-$ $-090 \mathrm{~g} / \mathrm{cm}^{3}$. Jest odporna na działanie kwasów i zasad. Rozpuszcza się w węglowodorach alifatycznych i aromatycznych, częściowo w olejku terpentynowym i w olejach schnących. Za: D. E. Olczak, op.cit., s. 52; Encyklopedia dla wssystkich. Chemia, Warszawa 2001, s. 267; Encyklopedia fisyki, t. 2: K-P, Warszawa 1972, s. 653; Encyklopedia techniki. Chemia, Warszawa 1993, s. 519; B. Slánský, Technika malarstwa, t. 1: Materiaty do malarstwa i konserwacji, Warszawa 1960, s. 96.

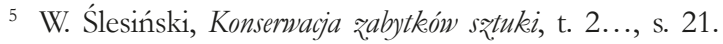

${ }^{6} \mathrm{~J}$. Lehmann, Konserwacja drewnianych zabytkón etnograficznych $i$ archeologicznych. Badania i prace nad metodykea, „Ochrona Zabytków” 1962, nr 1, s. 26.

7 S. M. Nakhla, A comparative study of resins for the consolidation of wooden objects, „Studies in Conservation" 1986, nr 1, s. 41, 43.

8 E. Packard, Conservation of decayed wood sculpture, Preprints of the Contributions to the New York Conference on Conservation of Stone and Wooden Objects, 7-13 June 1970, vol. 2: Conservation of Wooden Objects, London 1970, s. 13-22. Podaję na podstawie informacji zamieszczonych na http://www.bcin.ca (dostęp 2005.01.07).

9 J. Bursze, op.cit., s. 22. 


\section{Żywice aminowe}

O stosowaniu żywic aminowych do impregnacji drewna wzmiankowal W. Domasłowski. Zamieścił też charakterystykę tych związków ${ }^{10}$.

Do nasycania drewna stosowano roztwory żywic hydrofobowych w rozpuszczalnikach lotnych - stężony roztwór żywicy w butanolu rozcieńczony toluenem. 30-40\% roztwory żywicy mocznikowo-melaminowej wykazuja bardzo małą lepkość i dobrze przenikają w głąb drewna. Wadą jest konieczność stosowania kwasów mineralnych celem utwardzenia żywicy w temperaturze normalnej, co w sposób oczywisty ogranicza możliwości zastosowania w praktyce konserwatorskiej ${ }^{11}$. Potwierdza tę informacje J. Ciabach, podając, że w latach 60. roztwory tej żywicy były używane do wzmacniania mokrego, silnie zniszczonego drewna archeologicznego ${ }^{12}$. Z tego czasu pochodzi również wzmianka H. Krach, która żywicę melaminową wymienia w grupie środków, które należy brać pod uwagę wśród preparatów wykorzystywanych w pracach konserwatorskich przy obiektach zabytkowych ${ }^{13}$.

10 Żywice aminowe należą do związków termoutwardzalnych, przechodzących w produkt nietopliwy i nierozpuszczalny. Są bezbarwne i przeźroczyste, bezwonne, odporne na działanie światła, drobnoustrojów oraz olejów, są bardzo twarde, odporne na ścieranie lecz kruche. W zależności od stosunku formaldehydu do aminy oraz odczynu roztworu (kwaśny, zasadowy) otrzymuje się szereg żywicowanych produktów reakcji. Żywice niemodyfikowane są nierozpuszczalne w rozpuszczalnikach organicznych i mogą być otrzymywane jedynie w postaci roztworów wodnych. Jeżeli kondensację prowadzi się w obecności alkoholi (najczęściej butanolu), to otrzymuje się żywice estryfikowane o właściwościach hydrofobowych, które tracą zdolność rozpuszczania się w wodzie i stają się rozpuszczalne w rozpuszczalnikach organicznych (alkohole, estry, węglowodory aromatyczne). Podobnie jak żywice niemodyfikowane są one bezbarwne i przeźroczyste oraz utwardzają się w podobnych warunkach. Za: W. Domasłowski, Własności symic squtucznych oraz ich zastosowanie do prac konserwatorskich, „Materiały Zachodnio-Pomorskie” 1960, t. 6, s. 572$-573,576$.

11 Loc. cit.

12 J. Ciabach, Wtaściwości żymic sztucznych stosowanych w konserwacii zabytków, Torun 1997, s. 64 .

13 H. Krach, Środki i metody chemicznej konserwacï drewna w budowlach zabytkowych, "Zagadnienia Konserwacji Drewna”, Biblioteka Muzealnictwa i Ochrony Zabytków” 1961, seria B, t. 3, s. 83-86. 
Opisy konkretnych przykładów stosowania są w literaturze bardzo rzadkie ${ }^{14}$.

\section{Pochodne celulozy}

W zależności od rodzaju podstawników pochodne celulozy dzieli się na estry i etery. Do pierwszych należą azotany, octany, ksantogeniany oraz estry mieszane. Azotany określa się zwyczajowo mianem nitrocelulozy, natomiast octany mianem acetylocelulozy.

Nitroceluloza jest tworzywem o bardzo małej stabilności. Łatwo ulega fotooksydacji, ale nawet bez dostępu światła i w temperaturze pokojowej utlenianie się tego polimeru jest łatwe do zaobserwowania. Jego następstwem jest silne żółknięcie oraz pogorszenie rozpuszczalności i elastyczności wskutek sieciowania. Podobnie jak większość estrów azotany celulozy ulegaja hydrolizie. Wydzielający się kwas azotowy przyspiesza procesy starzenia i działa destrukcyjnie na znajdujące się w sąsiedztwie materiały. Produkowane na bazie nitrocelulozy kleje i lakiery sa ponadto łatwopalne i toksyczne ${ }^{15}$. Octany celulozy niemalże nie są wzmiankowane w literaturze

14 Spis dokumentacji konserwatorskich zabytkón ruchomych, cz. I: dla zabytków znajdujących się poza muzeami, O-Ż, Biblioteka Muzealnictwa i Ochrony Zabytków, ser. B, t. 39, 1975, s. 239.

15 Azotany celulozy powstają w wyniku działania na celulozę mieszaniny stężonego kwasu azotowego ze stężonym kwasem siarkowym lub innym środkiem wiążącym powstającą w reakcji wodę. Produkty handlowe są mieszaniną związków o różnym stopniu podstawienia - od nieprzereagowanej celulozy aż po produkt całkowitego podstawienia grup wodorotlenowych - trójazotan. Średni stopień podstawienia określa się procentową zawartością azotu. Rozróżnia się dwa zasadnicze gatunki handlowe: nitrocelulozę niskoazotową (11$-12 \%$ azotu) odpowiadająca w przybliżeniu dwuazotanowi oraz wysokoazotową (11-14\% azotu) odpowiadającą w przybliżeniu trójazotanowi. Nitroceluloza niskoazotowa rozpuszcza się w wielu cieczach organicznych, takich jak aceton, cykloheksanon, metanol, pirydyna, estry kwasu octowego, nitrobenzen i kwas octowy. Nitroceluloza wysokoazotowa rozpuszcza się w acetonie i cykloheksanonie, a nie rozpuszcza się w alkoholu metylowym i octanie butylu. Dwuazotan celulozy miesza się także z wieloma zmiękczaczami tworzyw sztucznych. Pierwszym zmiękczaczem pierwszego w historii tworzywa sztucznego była kamfora. W tej właśnie postaci dwuazotan celulozy znany jest od 1867 roku pod nazwą handlową celuloid. $\mathrm{Na}$ krótko przed I wojną światową kamforę zastąpiono fosforanem trójfenolu i trójkrezolu, a od lat 20. ubiegłego wieku zaczęto stosować ftalany, szczególnie ftalan dwubutylowy. 
jako materiały stosowane do konserwacji drewna. Znana jest mi jedynie lakoniczna wzmianka U. Schiessla o wykorzystaniu w przeszłości roztworów $\mathrm{w}$ acetonie do impregnacji ${ }^{16}$. Według B. Slánskiego azotany celulozy stosowano niekiedy do nasycania drewna ${ }^{17}$. W Ślesinski wymienia celuloid jako najstarsze spośród tworzyw sztucznych wykorzystywanych do utwardzania rzeźb z drewna. Podaje, że czysty rozpuszczony w acetonie celuloid o konsystencji słodkiej śmietany wprowadzano do drewna za pomocą strzykawki i pędzla. Jego zaletą miała być duża elastyczność i nieznaczna lepkość. Odporność na działanie światła oceniano jako średnią ${ }^{18}$. W. Domasłowski w 1961 r. stwierdza, że środkiem ówcześnie często używanym do nasycania drewna był azotan celulozy o dobrych właściwościach mechanicznych, jednakże dający roztwory o dużej lepkości nawet przy małych stężeniach. Zwracał uwage, że był on rozpuszczany w rozpuszczalnikach nienadających się do impregnacji drewna, jak aceton i octan etylu ${ }^{19}$. Znane sa jednak informacje o jego stosowaniu ${ }^{20}$, niekiedy w połączeniu z innymi żywicami ${ }^{21}$. I. Swaczyna natomiast, jeszcze w latach 90. XX wieku, wymienia nitrocelulozę

Współczesne azotany celulozy są bezbarwne, kruche i twarde, elastyczność uzyskują dopiero po splastyfikowaniu. Miękną w temperaturze około $80-90^{\circ} \mathrm{C}$, płyną przy $150^{\circ} \mathrm{C}$. Polimer jest kompatybilny z większością syntetycznych i naturalnych żywic. Jest odporny na wodę i relatywnie odporny na rozcieńczone kwasy i alkalia. Za, wraz z informacjami zawartymi w tekście: Adhesives and Coatings, „Conservation Science Teaching Series, Science for Conservators", vol. 3, Frome and London 1994, s. 44, 50, 112, 115; J. Ciabach, Wtaściwości $i$ zastosowanie estrón celulozy, „Ochrona Zabytków” 1990, nr 1, s. 50-51; idem, Wtaściności symic..., s. 91; Y. Shashona, S. M. Bardley, V. D. Daniels, Degradation of cellulose nitrate adhesives, „Studies in Conservation” 1992, nr 2, s. 114.

16 U. Schiessl, Probleme der Konservierungsstoffe zur Festigkeiterböhung von degradiertem Hol\%, [w:] M. Bildfinger, Meili D. (Herausgeber), Konservierung von Holzbauten, Bern und Stuttgart 1989, s. 101.

17 D. Slánský, op.cit., s. 107.

18 W. Ślesiński, Konserwacja zabytkón sz̨tuki, t. 2..., s. 21.

19 W. Domasłowski, Konserwacja..., s. 53, 54.

20 Spis..., s. 153; Spis dokumentacii konserwatorskich zabytkón ruchomych, cz. I: dla zabytków znajdujących się poza muzeami, A-N, Biblioteka Muzealnictwa i Ochrony Zabytków, ser. B, t. 39,1975 , s. 105.

21 Spis dokumentacii konserwatorskich zabytków ruchomych, cz. I: dla zabytków znajdujących się poza muzeami, O-Ż..., s. 149. Użyty został z chlorowanym polichlorkiem winylu, z informacją, że lakieru nitrocelulozowego użyto do części mniej zniszczonych. 
wśród rozpuszczalnikowych żywic syntetycznych stosowanych do wzmacniania drewna ${ }^{22}$.

\section{Żywica mocznikowa}

Badania nad zastosowaniem żywic mocznikowych do strukturalnego wzmacniania zniszczonego drewna prowadzone były głównie w latach 60 . i na początku 70. Przykłady stosowania, przytaczane w literaturze, sa jednak wcześniejsze - pochodzą z lat 50. W obiektach, gdzie użyto żywicy mocznikowej, nie była ona jedynym impregnatem - zastosowano ją równolegle z woskiem ${ }^{23}$ lub chlorowanym polichlorkiem winylu ${ }^{24}$.

Próby utwardzania tą żywicą zniszczonych materiałów porowatych, między innymi drewna, przeprowadził też W. Domasłowski. Nasycanie wykonano za pomoca pędzla, zastrzyków i przez zanurzenie. Badania nie dały całkowicie zadowalających rezultatów. Po utwardzeniu we wszystkich przypadkach powierzchnia impregnowanych materiałów stawała się mocna i twarda, wnętrze natomiast pozostawało nadal nieutwardzone. Przyczyny tego można upatrywać w powrotnej migracji impregnatu do powierzchni wskutek odparowywania rozpuszczalnika ${ }^{25}$.

H. Krach zaliczała żywice mocznikowe do grupy środków, które mogły być stosowane w obiektach zabytkowych „...do wypełniaczy ubytków drewna i powłok ochronnych..."

M. Czajnik badał właściwości żywicy mocznikowej, porównując ja z polioctanem winylu, polimetakrylanem metylu i żywicą epoksydową. Stwierdził, że porównawczo żywica mocznikowa w małym stopniu wpływa na ciężar właściwy drewna, w najmniejszym zmniejsza jego higroskopijność, korzystnie natomiast wpływa na obniżenie nasiąkli-

22 I. Swaczyna, Meble naprawa i odnawianie, Warszawa 1995, s. 66.

23. Spis dokumentacji konserwatorskich zabytków ruchomych, cz. I: dla zabytków znajdujących się poza muzeami, A-N..., s. 65.

24 Ibidem, s. 94.

25 W. Domasłowski, Wtasności..., s. 574.

${ }^{26}$ H. Krach, op.cit., s. 84-85. 
wości ${ }^{27}$. W nieco późniejszej publikacji autor ten wyraził również nadzieję na szersze zastosowanie żywic mocznikowych do wzmacniania drewna ${ }^{28}$.

Wyniki badań M. Czajnika na początku lat 90. przywołał J. Ważny rozwijając je o stwierdzenie, że badane żywice nadają się tylko do impregnacji drewna suchego ${ }^{29}$.

\section{Żywice cykloheksanonowe}

Również one należą do grupy żywic, na które zwrócono uwagę w latach 50. i 60. Są oligomerami o niedużej masie cząsteczkowej. Ich dużą zaletą jest rozpuszczalność w cieczach mało polarnych oraz wysoki współczynnik załamania światła związany z obecnością sześcioczłonowego pierścienia. Dobrze mieszają się z żywicami naturalnymi, estrami celulozy, polioctanem winylu, poliakrylanami, polimetakrylanami, poliamidami, żywicami mocznikowo-melaminowo-formaldehydowymi oraz olejami schnacymi - lnianym i tungowym. Wadą ich natomiast jest mała odporność na procesy autooksydacji, wynikajacca przede wszystkim z obecności grup karbonylowych oraz atomów wodoru związanych z trzeciorzędowymi atomami węgla. Pod wpływem światła żółkną oraz tracą rozpuszczalność w olejku terpentynowym, benzynie lakowej, toluenie, ksylenie i tym podobnych cieczach ${ }^{30}$.

27 M. Czajnik, Z badań nad zastosowaniem tworzyw sætucznych do konserwacii drewna, „Zeszyty Naukowe Szkoły Głównej Gospodarstwa Wiejskiego - Leśnictwo” 1968, nr 12, s. 81, 89.

28 M. Czajnik, Konserwacja..., s. 132.

29 J. Ważny, op.cit., s. 82.

30 Policykloheksanon jest produktem homopolikondensacji cykloheksanonu. Jest to żywica o małym ciężarze cząsteczkowym, dużej twardości i temperaturze topnienia $110-120^{\circ} \mathrm{C}$. Dodatek metylocykloheksanonu jako komonomeru powoduje zmniejszenie twardości, kruchości i obniżenie temperatury topnienia żywicy. Znane są też produkty heteropolikondensacji cykloheksanonu i metylocykloheksanonu z aldehydami. Za, wraz z informacjami zawartymi w tekście: J. Ciabach, Badania dotyczqce starzenia i stabilizacji wspótçesnych werniksów malarskich, Toruń 1994, s. 73-76; idem, Fotooksydacyjne starzenie sie powtok werniksu końcowego Rembrandt S.3 firmy Talens, „AUNC. Zabytkoznawstwo i Konserwatorstwo” 1990, XV, s. 24; idem, W Zaściwości i zastosowanie àywic cykloheksanonowych, „Ochrona Zabytków” 1991, nr 3, s. 209; idem, Wtaściwości ṡywic..., s. 96-97; M. Czajnik, Środki i metody konserwacij zabytkowego drewna budowlanego, „Ochrona Zabytków” 1968, nr 1, s. 25; W. Domasłowski, Konserwacja..., s. 54; E. R. de la Rie, A. M. Shedrinsky, The chemistry of ketone resins and the synthesis of deri- 
W. Kurpik zwraca uwage na niekorzystne właściwości mechaniczne żywicy policykloheksanonowej, na jej zbyt dużą kruchośćc ${ }^{31}$.

Według J. Ciabacha zwiększenie elastyczności żywicy cykloheksanonowej przez dodanie innego bardziej elastycznego polimeru napotyka na trudności. Pierwszą przeszkodą jest bardzo często występujący brak kompatybilności polimerów. Drugi problem związany jest z wpływem dodawanych polimerów na lepkość ciekłej i współczynnik załamania światła zestalonej żywicy. Niełatwy jest także problem stabilizacji żywic cykloheksanonowych. Najodpowiedniejsze wydają się fotostabilizatory typu HALS. Sa to pochodne 2,2,6,6-tetrametylopirydyny lub innych amin z zawada przestrzenna. Związki te są akceptorami wolnych rodników ${ }^{32}$.

O próbach, aczkolwiek nieudanych, zastosowania żywicy cykloheksanonowej Laropal K80 do impregnacji zniszczonego drewna pisała E. Ka$\operatorname{plan}^{33}$.

\section{Polistyren, żywice poliestrowo-styrenowe i poliestrowe}

Zainteresowanie tymi żywicami jako materiałem konserwatorskim sięga lat 50. i 60 .

Polistyren rozpuszcza się między innymi w węglowodorach aromatycznych, chlorowanych węglowodorach i estrach. Lepkość roztworów uzależ-

vative with increased stability and flexibility, „Studies in Conservation”1989, nr 1, s. 9; B. J. Rouba, „Przydatność farb akrylowych do restauracji obrazów”, Praca magisterska wykonana w Zakładzie Konserwacji Zabytków Ruchomych pod kierunkiem doc. Jerzego Wolskiego, Uniwersytet M. Kopernika, Toruń 1972, s. 10 (mps przechowywany w bibliotece ZKMiRP, nr 56).

31 W. Kurpik, „Ekstrakcja impregnatu z rzeźby polichromowanej”. (Praca magisterska), Katedra Technologii i Technik Malarskich Studium Zabytkoznawstwa i Konserwatorstwa przy Wydziale Sztuk Pięknych UMK, Torun 1962 r., s. 71 (mps przechowywany w bibliotece ZKMiRP, nr 24).

32 J. Ciabach, Wtaściwości i zastosowanie symic..., s. 211-212.

33 Informacja ta znana jest mi $\mathrm{z}$ abstraktu publikacji E. Kaplan, A comparison of four consolidants for degraded wood, Kingston 1993, zamieszczonego na http://www.bcin.ca (dostęp 2004.10.15). Ocena żywicy jest krótka, cytuję: „Laropal K80 was found to have unacceptable effects on several physical properties." 
niona jest od stopnia polimeryzacji. Wada powłok z polistyrenu jest ich kruchość i brak elastyczności oraz żółknięcie pod wpływem światła. Polistyren oceniany był jako produkt gorszej jakości, jednak pozwalający uzyskać dobre rezultaty przy impregnacji ${ }^{34}$. E. Voulgaridis i G. Passalis zwracaja uwagę na właściwości hydrofobizujące polistyrenu w stosunku do nasycanego drewna ${ }^{35}$. Literatura wzmiankuje też o konkretnych przykładach wykorzystania tej żywicy do impregnacji obiektów zabytkowych - rozpuszczonej w czterochlorku węgla $z$ dodatkiem katalizatora ${ }^{36}$ bądź używanej wymiennie, w jednym obiekcie, z kalafonią $a^{37}$.

Do impregnacji drewna, szczególnie bardzo zniszczonego, stosowane były również żywice poliestrowe ${ }^{38}$ i poliestrowo-styrenowe o małej lepkości. Przed impregnacja należało w żywicy rozpuścić inicjator i aktywator w takich ilościach, aby żywica nie żelowała zbyt szybko. W celu zmniejszenia lepkości i zapewnienia lepszego przenikania roztworu można było dodać styrenu jako rozcieńczalnika ${ }^{39}$, co jednak mogło niekorzystnie wpływać

34 Polistyren otrzymywany jest przez polimeryzację styrenu $\left(\mathrm{C}_{6} \mathrm{H}_{5}-\mathrm{CH}=\mathrm{CH}_{2}\right)$. Polimer jest bezbarwny, przepuszcza do $90 \%$ światła widzialnego, i twardy. Należy do żywic bardzo odpornych na działanie wody, zasad, kwasów oraz niskiej temperatury. Jego odporność na podwyższona temperaturę jest uzależniona od stopnia polimeryzacji i wynosi przeciętnie około $80^{\circ} \mathrm{C}$. Polimer ogrzewany najpierw mięknie, a następnie w miarę wzrostu temperatury przechodzi w stan półciekły $\left(120-150^{\circ} \mathrm{C}\right)$. Za, wraz z informacjami zawartymi w tekście: M. Czajnik, Środki..., s. 26; W. Domasłowski, Konserwacja..., s. 55; idem, Wtasności..., s. 590-591; A. J. Lazariew, M. F. Sorokin, Żywice syntetyczne, Warszawa 1957, s. 261; B. Slánský, op.cit., s. 104.

35 E. Voulgardis, C. Passalis, Preliminary studies on water repellent properties of reclaimed polystyrene applied small wood specimens. I. Initial efficiency, „Holzforschung und Holzverwertung” 1982, nr 5, s. 66-69. Podaję na podstawie informacji zawartych na http://www.bcin.ca (dostęp 2005.01.05).

36 Spis dokumentaci konserwatorskich zabytków ruchomych dla zabytków znajdujacych sie poza muzeami, O-Ż..., s. 104.

37 Ibidem, s. 105.

38 R. A. Munnikendam, Low molecular epoxy resins for the consolidation of decayed wooden objects, „Studies in Conservation” 1972, nr 4, s. 202; H. J. Plenderleith, The Conservation of Antiquities and Works of Art. Treatment, Repair and Restoration, London 1956, s. 130; E. De Witte, A. Terfve, The use of PY-GC-MS techniques for the analysis of synthetic resins, [w:] Science and technology in the service of conservation. Preprints of the contributions to the Washington congress, 3-9 September 1982, London 1982, s. 18.

39 M. Czajnik, Konserwacja drewna środkami chemicznymi, [w:] Muzea skansenowskie w Polsce, Poznań 1979, s. 250; idem, Środki..., s. 26; W. Domasłowski, K. Powidzki, Badania nad 
na warstwy malarskie ${ }^{40}$. Informacje o możliwości stosowania nienasyconych żywic poliestrowych do impregnacji materiałów porowatych podaje również J. Ciabach. Tego rodzaju żywice można utwardzić w wyniku polimeryzacji kondensacyjnej lub addycyjnej ${ }^{41}$.

\section{Żywice formaldehydowe}

Żywice formaldehydowe próbowano stosować do konserwacji drewna zabytkowego w latach 50. Dużym zainteresowaniem cieszyły się żywice fenolowo-formaldehydowe, krezolowo-formaldehydowe, rezorcynowo-formaldehydowe i mocznikowe ${ }^{42}$.

Otrzymywane są one przez kondensacje fenolu $\left(\mathrm{C}_{6} \mathrm{H}_{5} \mathrm{OH}\right)$, krezoli $\left(\mathrm{CH}_{3}-\mathrm{C}_{6} \mathrm{H}_{4} \mathrm{OH}\right)$ lub rezorcyny $\left(\mathrm{C}_{6} \mathrm{H}_{4}(\mathrm{OH})_{2}\right)$ z formaldehydem $\left(\mathrm{CH}_{2} \mathrm{O}\right)$. W zależności od rodzaju użytego fenolu oraz od rodzaju katalizatora (kwaśny, zasadowy) otrzymuje się żywice nowolakowe, rezolowe (hydrofobowe i hydrofilowe), rezorcynowe, fenolowo-rezorcynowe oraz modyfikowane żywice fenolowe ${ }^{43}$.

Nowolakowe żywice fenolowo-formaldehydowe sa polimerami termoplastycznymi. W zależności od warunków kondensacji i czystości surowców otrzymuje się żywice o lekkim lub znacznym zabarwieniu. Są to żywice twarde i kruche. Rozpuszczają się w alkoholu etylowym, tworząc roztwory o małej lepkości, dobrze przenikające w głab materiałów porowatych. Nowolaki ciemnieja pod wpływem światła i wykazuja niedostateczną odporność na działanie wody. Elastyczność ich można zwiększyć, stosując

zastosowaniem roztworów symic epoksydowych do impregnacji (wrmacniania) drewna, „Zeszyty Naukowe Uniwersytetu Mikołaja Kopernika w Toruniu” 1968, III, s. 194; W. Domasłowski, Wtasności..., s. 579.

40 R. Munnikendam, Consolidation of fragile wood with low viscosity aliphatic epoxy resins, [w:] Conservation of Wood in Painting and Decorative Arts, Preprints of the Contributions to the Oxford Congress, 17-23 September 1978, London 1978, s. 71.

${ }^{41}$ J. Ciabach, Wtaściności symic..., s. 65, 68.

42 W. Domasłowski, K. Powidzki, op.cit., s. 195; D. E. Olczak, op.cit., s. 52.

43 W. Domasłowski, Własności..., s. 569; B. Slánský, op.cit., s. 105. 
zmiękczacze, na przykład fosforan trójkrezolowy ${ }^{44}$. Ciekłą żywicą uszlachetniano drewno przemysłowe. Po nasyceniu drewno ogrzewano w podwyższonej temperaturze, dzięki czemu żywica ciekła (tzw. rezol) przechodziła w stan stały (tzw. rezit), wypełniając pory w drewnie, zwiększając jego odporność mechaniczną oraz na działanie czynników niszczących. Ze względu na konieczność między innymi długotrwałego ogrzewania omawiana żywica nie nadawała się do konserwacji obiektów zabytkowych ${ }^{45}$. Roztwory spirytusowe nowolaków były stosowane jako namiastka szelaku, o ile nie była wymagana bezbarwność i duża odporność materiału ${ }^{46}$.

Kurpik wzmiankował o możliwości utwardzania powierzchni przygotowanej do sklejania, o ile nie stanowiła ona odwrotnej strony elementu polichromowanego, roztworem kleju AG, będącego również produktem kondensacji fenolu i formaliny. Jako utwardzacza używano najczęściej kwasu naftaleno-sulfonowego lub kwasów mineralnych. Budziło to zastrzeżenia ze względu na działanie hydrolizujące utwardzacza na tkankę drzewną ${ }^{47}$.

Żywicę fenolowo-formaldehydowa dla celów konserwatorskich modyfikowano poprzez dodanie kalafonii lub kwasu abietynowego. Uzyskaną kwaśną żywicę poddawano estryfikacji alkoholem wielowodorotlenowym, co pozwalało na zmniejszenie kwasowości i zwiększenie odporności na działanie wody oraz polepszenie rozpuszczalności w węglowodorach. Otrzymane produkty znane były pod nazwa albertole. Należały one do żywic trwale termoplastycznych, o temperaturze topnienia w granicach $70-100^{\circ} \mathrm{C}$. W zależności od sposobu otrzymywania i czystości surowców uzyskiwano żywice jasne (z kwasem abietynowym) lub zabarwione. Odznaczały się one lepszą odpornością na działanie czynników atmosferycznych i światła niż nowolaki. Rozpuszczały się w mieszaninie węglowodorów aromatycznych i alkoholu oraz w olejach. Albertole tworzyły roztwory o małej lepkości,

44 W. Domasłowski, Wtasności..., s. 569.

45 W. Domasłowski, Konserwacja..., s. 57-58.

46 W. Domasłowski, Wtasności..., s. 569.

47 W. Kurpik, Utwardzanie zniszczonego drewna pray pomocy symic syntetycznych. Wykonywanie plomb trocinowych, „Materiały Muzeum Budownictwa Ludowego w Sanoku” 1966, nr 6, s. 28-29. 
dzięki czemu były stosowane do impregnacji ${ }^{48}$. Nasycano nimi między innymi drewno rzeźb ${ }^{49}$.

Żywice rezorcynowe i rezorcynowo-fenolowo-formaldehydowe również należą do żywic termoutwardzalnych. Ich podstawową zaletą jest możliwość utwardzania na zimno i w środowisku obojętnym. Żywice czyste i modyfikowane fenolem były całkowicie odporne na działanie zimnej i goracej wody, alkaliów, kwasów i mikroorganizmów. Po utwardzeniu określane były jako nierozpuszczalne i nieulegające starzeniu. Można z nich było przygotowywać roztwory wodne, alkoholowe, a także w innych rozpuszczalnikach organicznych. Do wad tych żywic należało ciemne zabarwienie. Były polecane między innymi jako środki impregnujące do materiałów porowatych. Stosowano tu roztwory alkoholowe o stężeniu od 20 do 50\%, stwierdzając, że zaimpregnowane nimi drewno zyskuje większą odporność na wahania temperatury i wilgotności oraz niszczące działanie mikroorganizmów i czynników mechanicznych ${ }^{50}$.

W literaturze można napotkać przykłady impregnacji drewnianych obiektów polichromowanych żywicą rezorcynową ${ }^{51}$.

Podobne żywice utwardzalne otrzymywano przez kondensacje mocznika i melaminy z formaldehydem. Podczas utwardzania przechodza one $\mathrm{z}$ postaci rozpuszczalnej $\mathrm{w}$ nierozpuszczalną. Proces ten zachodzi pod wpływem kwaśnych utwardzaczy lub temperatury. Były to żywice bezbarw-

48 J. Ciabach, Wtaściwości śymic..., s. 63; W. Domasłowski, Wtasności..., s. 571-572; K. Dąbrowska, „Konserwacja polichromii gotyckiej rzeźby drewnianej na podstawie przeprowadzonej konserwacji figury Matki Boskiej ze Słupcy”, Praca magisterska, Toruń 1955, s. 92 (mps przechowywany w bibliotece ZKMiRP, nr 7); A. Dworakowska, Konserwacja XVI-wiecznego Krucyfiksu z. Maszewa, „Materiały Zachodnio-Pomorskie” 1956, t. 2, s. 313.

49 K. Dąbrowska, op.cit., s. 10, 91-92; A. Dworakowska, „Konserwacja i ewentualna rekonstrukcja polichromii rzeźby drewnianej" (praca magisterska), Zakład Technologii i Technik Malarskich Studium Konserwatorstwa i Muzealnictwa przy Wydziale Sztuk Pięknych Uniwersytetu Mikołaja Kopernika w Toruniu 1955 r (mps przechowywany w bibliotece ZKMiRP, nr 9), s. 4, 33-34; EADEM, Konserwacja XVI-wiec₹nego..., s. 309, 313; Spis dokumentacji konserwatorskich zabytków ruchomych, cz. I: dla zabytków znajdujących się poza muzeami, O-Ż..., s. 59.

50 W. Domasłowski, Wtasności..., s. 571; W. Ślesiński, Konserwacja zabytkón sq̨uki, t. 1..., s. 24; idem, Konserwacja zabytkón sztuki, t. 2.., s. 23.

51 Spis dokumentacii konserwatorskich zabytkón ruchomych, cz. I: dla zabytków znajdujących się poza muzeami, A-N..., s. 89-90. 
ne i przeźroczyste, odporne na działanie promieni UV, podwyższonych i niskich temperatur, słabych kwasów i zasad, a także twarde, odporne na ścieranie, ale kruche. Główną wadą żywic mocznikowych była mała odporność na działanie wody. Dlatego do impregnacji drewna używano najczęściej żywic melaminowych lub mocznikowo-melaminowych. Impregnacja drewna roztworami żywicy mocznikowo-melaminowo-formaldehydowej pozwalała uzyskać dość duży stopień nasycenia drewna, szczególnie przy zastosowaniu metody elektroosmotycznej ${ }^{52}$. Zakres stosowania tej metody ograniczono do obiektów niepolichromowanych ze względu na użycie roztworów wodnych ${ }^{53}$.

Wzmianki o stosowaniu żywicy określanej w uproszczeniu jako mocznikowa do nasycania obiektów polichromowanych są nieliczne. Obejmuja przykłady użycia jej w jednym obiekcie wymiennie z woskiem lub chlorowanym polichlorkiem winylu ${ }^{54}$.

\section{Polimery i kopolimery winylowe}

Polimery i kopolimery winylowe stanowia grupę żywic powszechnie stosowanych w praktyce konserwatorskiej, stąd długotrwałe i ciagle duże zainteresowanie ich przydatnością do wzmacniania materiałów porowatych jest uzasadnione i zrozumiałe.

52 W. Domasłowski, K. Powidzki, op.cit., s. 195-196; Wzmiankę o stosowaniu żywic mocznikowo- i melaminowo-formaldehydowych zawiera również abstrakt publikacji zamieszczony na http://www.bcin.ca (dostęp 2005.01.17): E. B. Trostyanskaya, G. N. Tomashevich, E. V. Sorokina, Consolidation and restoration of woodwork, [w:] Problems of Restoration and Conservation of Works of Fine Art. Methodical Textbook, 1960. Oryginalnego tytułu i miejsca wydania nie podano, brak też określenia typu publikacji.

53 H. Wołujewicz, Badania nad wżmacnianiem drewna ræę́b nie polichromowanych, „Zeszyty Naukowe Uniwersytetu Mikołaja Kopernika. Zabytkoznawstwo i Konserwatorstwo” 1966, II, s. 246-249.

${ }^{54}$ Spis dokumentacij konserwatorskich zabytkón ruchomych, cz. I: dla zabytków znajdujących się poza muzeami, A-N..., s. 65, 96. 
Najmniej liczne są wzmianki o stosowaniu polialkoholu winylowego ${ }^{55}$. Jedynie W. Ślesiński pisze o stosowaniu 10-15\% roztworów w benzynie lakowej lub w ksylenie ${ }^{56}$.

Produktami kondensacji polialkoholi winylowych ze związkami karbonylowymi (aldehydami lub ketonami) są poliacetale winylowe ${ }^{57}$. Można je otrzymywać także z polioctanu winylu, na który działa się kwasami i aldehydami. Ich właściwości fizyczne zależą od wzajemnego stosunku grup acetalowych i hydroksylowych, stopnia polimeryzacji oraz rodzaju aldehydu. Im dalej leży aldehyd w szeregu homologicznym, tym dłuższe są boczne łańcuchy polimeru, co powoduje obniżenie jego odporności na działanie ciepła. Istotne znaczenie ma stopień zacetalowania. Im jest on wyższy, tym niższa jest temperatura mięknienia żywicy. Niski stopień zacetalowania powoduje częściową rozpuszczalność tworzywa w wodzie. Na stopień polimeryzacji wpływa także wielkość cząsteczki polialkoholu winylowego. Wszystkie gatunki poliwinyloacetali są nieco wrażliwe nadziałanie wody i węglowodorów. Najlepszymi ich rozpuszczalnikami są niższe alkohole lub ich mieszaniny z węglowodorami aromatycznymi, ketony oraz estry ${ }^{58}$.

\footnotetext{
55 Polialkohol winylowy to żywica bezbarwna, o temperaturze zeszklenia $85^{\circ} \mathrm{C}$, mięknienia $150-160^{\circ} \mathrm{C}$. W trakcie ogrzewania nie uelastycznia się i nie topi. Rozpuszcza się w wodzie, wodnych roztworach kwasu octowego i mrówkowego oraz na ciepło w silnie polarnych cieczach organicznych, miedzy innymi w formamidzie i w dwumetyloformamidzie, glikolu etylenowym i glicerynie. Za: V. Kyzelyte, „Możliwości wzmacniania płócien zabytkowych". Praca magisterska napisana pod kierunkiem prof. dr Bogumily Rouby, we współpracy z dr hab. Jerzym Ciabachem, Uniwersytet Mikołaja Kopernika, Wydział Sztuk Pięknych, Zakład Konserwacji Malarstwa i Rzeźby Polichromowanej, Toruń 2002, s. 61 (mps przechowywany w bibliotece ZKMiRP); B Slánský, op. cit., s. 102.

56 W. Ślesiński, Konserwacja zabytków sžtuki, t. 1..., s. 23; idem, Konserwacja zabytków sæ̨tuki, t. $2 \ldots$, s. 22.

57 R. Biliński, Ocena praydatności niektórych tworyyw winylowych do konserwacï zabytków, „Ochrona Zabytków" 1961, nr 3-4, s. 89.

58 J. Ciabach, Wtaściności s̀ywic..., s. 52; K. A. Krzyżyński, „Badania nad stabilizacją podobrazia drewnianego". Praca magisterska napisana przy Katedrze Technologii i Technik Malarskich Wydziału Sztuk Pięknych w Toruniu pod kierunkiem doc. Jerzego Wolskiego, Toruń 1968, s. 23-24 (mps przechowywany w bibliotece ZKMiRP, nr 41).
} 
Polibutyral winylowy ${ }^{59}$ jest najbardziej znanym z poliacetali60 ${ }^{60}$ Cechuje go duża higroskopijność i niska temperatura zeszklenia, ponadto zaliczany jest do grupy żywic mało odpornych na działanie promieniowania ultrafioletowego, ulegających sieciowaniu z wydzieleniem produktów lotnych. Odporność biologiczną poliwinylobutyralu uważa się za zadowalającą ${ }^{61}$. Literatura przedmiotu wzmiankuje badania nad zastosowaniem poliwinylobutyralu do impregnacji drewna wskazując na uzyskiwaną w jej efekcie poprawę właściwości mechanicznych ${ }^{62}$ oraz odnotowuje przykłady stosowania ${ }^{63}$.

R. Biliński pracując nad uzyskaniem tworzywa przydatnego do zabezpieczania obiektów zabytkowych otrzymał poliwinyloacetal mieszany: etylalowo-krotonowy, cechujący się wysoką wytrzymałością mechaniczna, znaczną wodo- i termoodpornością oraz stabilnością wobec czynników at-

59 Polibutyral winylowy otrzymywany jest przez działanie aldehydu masłowego na polialkohol winylowy. Jest on polimerem bezbarwnym i przeźroczystym. Posiada wiele cennych zalet, jednak rozpuszcza się łatwo tylko w niższych alkoholach i ich mieszaninach z innymi cieczami organicznymi, na przykład estrami lub ketonami. Podstawowym jego rozpuszczalnikiem jest $96 \%$ alkohol etylowy. Żywica ta miesza się z wieloma żywicami naturalnymi, takimi jak kalafonia i szelak oraz sztucznymi: z nowolakiem, niektórymi gatunkami nitrocelulozy i żywic epoksydowych. Za: J. Ciabach, Badania nad przemianami symic termoplastycznych pod wplywem promieniowania nadfioletowego, Toruń 1982, s. 42; idem, Wtaściwości synwic..., s. 53-54; W. Domasłowski, Konserwacja..., s. 56; C. V. Horie, Materials for Conservation, Butterwarths London Boston Durban Singapore Sydney Toronto Wellington 1978, s. 100.

${ }^{60}$ S. M. Carlson, A. P. Schniewind, Residual solvents in wood-consolidant composities, "Studies in Conservation", nr 1, 1990, s. 26; W. Domasłowski, Konserwacja..., s. 56; J. Krawczyk, Badania naukowe w analizie i konserwacji mebli zabytkonych, „Ochrona Zabytków”, nr 1-2, 1992, s. 39 .

${ }^{61}$ J. Ciabach, Badania..., s. 49-50; idem, Wtaściności ṡymic..., s. 54; C. V. Horie, op.cit., s. 100, 102; M. Wierucka, „Badanie polialkoholi winylowych do utrwalania łuszczących się malowideł ściennych na podłożu drewnianym”. Praca magisterska wykonana w Zakładzie Konserwacji Malarstwa i Rzeźby Polichromowanej. Promotor prof. dr Bogumiła Rouba, prof. dr Maria Roznerska przy współpracy dr Ewy Roznerskiej-Swierczewskiej, Uniwersytet Mikołaja Kopernika, Toruń 2002, s. 31 (mps przechowywany w bibliotece ZKMiRP, nr 227).

${ }^{62}$ C. V. Horie, op. cit., s. 102; E. Kaplan, op. cit. podaję na podstawie informacji zamieszczonych na http://www.bcin.ca (dostęp. 2004.10.15); S. M. Nakhla, A comparative study of resins for the consolidation of decayed wooden objects, „Studies in Conservation”, nr 4, 1972, s. 41, 43; Y. Wang, A. P. Schniewind, Consolidation of deteriorated wood with soluble resins, ,Journal of the American Institute for Conservation", nr 2, s. 77-91. Podaję na podstawie informacji zamieszczonych na http://www.bcin.ca (dostęp 2005.01.05).

${ }^{63}$ R. L. Barclay, Wood consolidation on an eighteenth century English fire engine, „Studies in Conservation", nr 4, 1981, s. 135; S. M. Nakhla, op.cit., s. 41-43. 
mosferycznych i biologicznych ${ }^{64}$. W latach 60 . i 70. spoiwo to było stosowane do impregnacji drewna zabytkowego ${ }^{65}$.

W latach 60. i na początku 70. do utwardzania drewna stosowano chlorowany polichlorek winylu ${ }^{66}$. Jest to polimer o niskim stopniu polimeryzacji, tworzy więc roztwory o małej lepkości, przez co możliwe jest uzyskanie dużego stężenia żywicy w roztworze. Rozpuszcza się między innymi w toluenie, chlorobenzenie i dwuchloroetanie. Do impregnacji stosowane były roztwory 15-30\%. Nasycone drewno miało uzyskać wysoką wytrzymałość mechaniczna. Wadą tej żywicy była mała odporność na procesy starzeniowe, zachodzące zarówno pod wpływem temperatury, jak i światła, w szczególności promieniowania ultrafioletowego. W ich wyniku odszczepia ona chlorowodór, utlenia się, sieciuje i wyraźnie żółknie ${ }^{67}$.

Oprócz pozycji zamieszczających charakterystykę i zalecenia odnośnie do stosowania superchlorku winylu literatura przedmiotu podaje także konkretne przykłady zastosowania. Najczęstszymi wymienianymi rozpuszczalnikami roztworów impregnacyjnych są chloroetylen, chlorobenzen, toluen. Niekiedy nasycanie superchlorkiem winylu łączono w jednym obiekcie z impregnacją żywica mocznikowa, kalafonią, Vinoflexem, bądź nitrolakierem $^{68}$.

${ }^{64}$ R. Biliński, op. cit., s. 90-91.

${ }^{65}$ J. Nykiel, Uwagi na temat technologii materiatón stosowanych przez profesora Józefa E. Dutkiewicza, [w:] Studia i Materialy Wydziatu Konserwacji i Restauracji Dziet Sztuki Akademii Sztuk Pieknych w Krakowie, t. IX, cz. 1: Drogi wspótczesnej konserwacji. Aranżacja, Ekespożyja. Rekonstrukcja. Profesorowi Józefowi E. Dutkiewiczowi w 30 rocznicę śmierci, Kraków 1999, s. 64.

${ }^{66}$ B. Chaber, „Badania nad impregnacją desek podobrazi roztworami żywicy epoksydowej Epidian 5." Praca magisterska wykonana w katedrze Technologii i Technik Malarskich Wydziału Sztuk Pięknych UMK w Toruniu pod kierunkiem doc. dr. W. Domasłowskiego, s. 10 (mps przechowywany w bibliotece ZKMiRP, nr 47).

${ }^{67}$ Loc. cit.; J. Ciabach, Wtaściności ṡywic..., s. 43; M. Czajnik, Środki..., s. 26; W. Domasłowski, Konserwacja..., s. 55; idem, Wtasności..., s. 598-599; idem, Zagadnienie konserwacji drewna, Materiały Zachodnio-Pomorskie, t. 4, 1958, s. 401, 404; C. V. Horie, op.cit., s. 32; A. Szczepkowski, Uzupetnianie drewnianych podobraz̧i i elementów ręébiarskich w Pracowni Konserwatorskiej MBL, „Materiały Muzeum Budownictwa Ludowego w Sanoku”, nr 16, 1972, s. 10 .

68 M. Czajnik, P. Rudniewski, D. Tworek, Niektóre zagadnienia z. prac nad konserwacja elementów drewnianych, „Ochrona Zabytków” 1962, nr 3, s. 79; B. Hirszenberg, Sprawozdanie z akciji zabezpieczania ikon przeprowadzonej w roku 1965 przez Pracownie Konserwatorska MBL w Sanoku

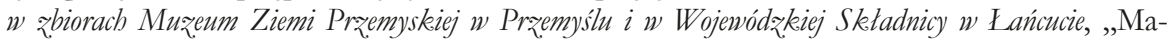


Kolejnym z grupy polimerów winylowych jest polioctan winylu, otrzymywany w wyniku polimeryzacji rodnikowej octanu winylu. Jest to żywica bezbarwna i przeźroczysta. Należy do żywic miękkich i elastycznych ${ }^{69}$. Błony polioctanu winylu posiadaja ponadto właściwości autoadhezyjne ${ }^{70}$. Charakterystyka polimeru jest zmienna w zależności od jego ciężaru cząsteczkowego. Generalnie rozpuszcza się w węglowodorach aromatycznych, estrach, ketonach i alkoholach, szczególnie w metanolu. Etanol, propanol i butanol są dobrymi rozpuszczalnikami jeżeli zawierają od 4 do $8 \%$ wody oraz kilka procent octanu etylu bądź benzenu. Czysty, dobrej jakości polioctan winylu ulega pod wpływem promieniowania nadfioletowego powolnej degradacji, ale nie żółknie. Jest to żywica o niskiej odporności cieplnej, chemicznej i mikrobiologicznej ${ }^{71}$.

teriały Muzeum Budownictwa Ludowego w Sanoku" 1966, nr 4, s. 71-72; Spis dokumentacii konserwatorskich zabytków ruchomych, cz. I: dla zabytków znajdujących się poza muzeami, A-N..., s. 96, 107, 123, 132, 158-159, 249; Spis dokumentacji konserwatorskich zabytków ruchomych, cz. I: dla zabytków znajdujących się poza muzeami, O-Ż..., s. 21, 149, 162, 213.

${ }_{69}$ Adhesives..., s. 51; J. Cabach, Wtaściwości ṡymic..., s. 46-47; M. Czajnik, Środki..., s. 26; W. Domasłowski, Konserwacja..., s. 54; R. Kozłowski, Prostowanie spaczonych podobrazi drewnianych za pomoca zabiegów chemicznych i mechanicznych, „Ochrona Zabytków” 1960, nr 1-4, s. 60; idem, Prostowanie spaczonych podobrazi drewnianych za pomoca zabiegón chemicznych i mechanicznych, „Zagadnienia konserwacji drewna, Biblioteka Muzealnictwa i Ochrony Zabytków", seria B, t. 3, 1961, s. 124; H. Krach, Chemia stosowana w drzennictwie, Warszawa 1973, s. 233-234; V. Kyzelyte, op.cit., s. 59; B. Sl?nsky, op. cit., s. 102; W Ślesiński, Konserwacja zabytków sztuki, t. 1..., s. 23; idem, Konserwacja zabytkón sұtuki, t. 2..., s. 22; K. Wieczorek, Krajowe środki do ochrony $i$ konserwacji drewna w zabytkach, Warszawa 1992, s. 93; M. Wierucka, op.cit., s. 31.

${ }_{70}$ R. Biliński, op.cit., s. 83-84.

${ }^{71}$ Żywice o niewielkich makrocząsteczkach są kleiste, łatwo płyna, nawet w temperaturze pokojowej, ogrzane topią się, a w niskich temperaturach stają się kruche. Tworzą roztwory o małej lepkości. Polimery o znacznym ciężarze ogrzewane nie topią się, lecz stają się gumowate, a w temperaturze $130^{\circ} \mathrm{C}$ ulegaja rozkładowi z wydzieleniem kwasu octowego. W niskich temperaturach zachowują pewną twardość i spoistość. Rozpuszczają się źle, tworząc nawet przy małych stężeniach roztwory o dużej lepkości. Polimer ten ma budowę bezpostaciowa, wynikająca prawdopodobnie z asymetrycznego ustawienia atomów węgla, co powoduje powstawanie izomerii przestrzennej. Za, wraz z informacjami zawartymi $\mathrm{w}$ tekście: Adhesives..., s. 51; J. Ciabach, Wtaściwości symic..., s. 47-48, M. Czajnik, Środki..., s. 26; W. Domasłowski, Konserwacja..., s. 54-55; H. Krach, Chemia..., s. 233-234; K. A. Krzyżyński, op.cit., s, 25-26; W. Kurpik, Ekstrakcja..., s. 71; V. Kyzelyte, op.cit., s. 59; W. Ślesiński, Konserwacja zabytków sұtuki, t. 2..., s. 22; K. Wieczorek, op.cit., s. 93. 
Do impregnacji stosowany był w postaci dyspersji wodnej, czasem $\mathrm{z}$ dodatkiem etanolu ${ }^{72}$ oraz roztworów, głównie w metanolu, etanolu, acetonie, rzadziej w mieszaninie rozpuszczalników, przykładowo toluenu i acetonu ${ }^{73}$. Niekiedy składnikiem impregnatów były tez środki biobójcze - literatura wymienia między innymi sublimat ${ }^{74}$.

Soldenhoff przeprowadziła badania porównawcze efektów impregnacji polioctanem winylu oraz kopolimerami akrylowymi. Stwierdziła, że drewno nasycone wszystkimi badanymi żywicami miało mniejszą higroskopijność $\mathrm{w}$ porównaniu $\mathrm{z}$ drewnem zdrowym nieimpregnowanym. Zwiększeniu uległa też wytrzymałość mechaniczna. Jednak drewno nasycone polioctanem

72 H. Janse, Die Konservierung von Dachstüblen und Holzgerüstkonstruktionen aus dem Mittelalter und dem 17. in den Nederlanden, „Deutsche Kunst und Denkmalpflege”, H. 2, 1969, s. 162; Spis dokumentacji konserwatorskich zabytkón ruchomych, cz. I: dla zabytków znajdujących się poza muzeami, A-N..., s. 102, 195.

73 R. Biliński, op.cit., s. 85; L. Czubiel, Prace konserwatorskie w wojewódz̨twie olsatyńskim w latach 1961-1967 (c\%. I), „Ochrona Zabytków” 1968, nr 4, s. 46; R. Kozłowski, Prostowanie spaczonych podobrazi drewnianych za pomoca zabiegón chemicznych i mechanicznych, „Ochrona Zabytków” 1968, nr 4, s. 60; idem, Prostowanie spaczonych podobrazi drewnianych za pomoca zabiegów chemicznych i mechanicznych, "Zagadnienia Konserwacji Drewna, Biblioteka Muzealnictwa i Ochrony Zabytków” 1961, ser. B, t. 3, s. 124; S. M. Nakhla, op.cit., s. 38, 41; H. J. Plenderleith, op. cit., s. 130; E. Schaffer, Consolidation of softwood artifacts, „Studies in Conservation” 1971, nr 3, s. 110-113; U. Schiessl, op. cit., s. 101; W. Ślesiński, Konserwacja zabytkón sztuki, t. 1..., s. 23; Spis dokumentacii konserwatorskich zabytków ruchomych, cz. I: dla zabytków znajdujących się poza muzeami, A-N..., s. 169, 202, 229-230, 262-263, 279, 281-282; Spis dokumentacii konserwatorskich zabytków ruchomych, cz. I: dla zabytków znajdujących się poza muzeami, O-Ż..., s. 11-12, 98, 103-104, 109, 111, 163, 221; K. Wieczorek, op.cit., s. 94.

74 Spis dokumentacii konserwatorskich zabytków ruchomych, cz. I: dla zabytków znajdujących się poza muzeami, A-N..., s. 169, 229-230, 281-282; Sublimat $\mathrm{HgCl}_{2}$. Biały krystaliczny proszek rozpuszczalny w wodzie, benzynie, eterze i alkoholu. Jest on bardzo silnie toksyczny zarówno w stosunku do grzybów, jak i owadów. Jego wadami są zbyt szybkie utrwalanie się w drewnie i przez to ograniczenie głębokości wnikania, korodowanie metali oraz bardzo znaczne obniżanie pH do około 3. Za: S. Jędrzejewska, P. Rudniewski, A. Wawrzyńczak, Substancje s₹kodliwe dla zdrowia stosowane w konserwacji dziet sұtuki, Warszawa 1974, s. 46; J. Kehl, Wykaz zoniazków i preparatón chemicznych stosowanych w konserwacii zabyttón, Warszawa 1985, s. 126; Stownik polskiej terminologii technik $i$ technologii konserwacji malarstwa sұtalugowego, ściennego i ræę̧́́y polichromowanej, „Biblioteka Muzealnictwa i Ochrony Zabytków”, seria B, t. 78, s. 54; K. Szczepińska, „Problem likwidacji zaplamień po impregnacji środkami oleistymi malowideł ściennych na drewnie". Praca magisterska pod kierunkiem prof. dr Marii Roznerskiej i mgr Ewy Roznerskiej-Świerczewskiej, Zakład Konserwacji Malarstwa i Rzeźby Polichromowanej Instytut Zabytkoznawstwa i Konserwatorstwa Uniwersytet Mikołaja Kopernika, Toruń 1997, s. 31-32 (mps, egzemplarz własny). 
winylu wykazywało nieco gorsze właściwości od impregnowanego żywicami akrylowymi ${ }^{75}$. Podobne wyniki uzyskał M. Paciorek. Ponadto niezadawalające były rezultaty odnośnie do rozmieszczenia tworzywa w drewnie, ze względu na duże zróżnicowanie gęstości w partiach drewna wczesnego i późnego oraz ze względu na znaczne uszczelnienie warstw przypowierzchniowych ${ }^{76}$.

Jako impregnaty stosowano również roztwory alkoholowe, głównie w metanolu, i acetonowe acetalowanego polioctanu winylu. Jako dodatek pojawiał się też parachlorometakrezol. Acetalowany polioctan winylu jest odporny na długotrwałe działanie pary wodnej, a nawet wody ciekłej. Charakteryzuje go stabilność wobec wielu czynników szkodliwych. Odznacza się odpornością na działanie światła słonecznego i nie zmienia swoich cech pod wpływem niskich temperatur ${ }^{77}$.

Do wzmacniania drewna stosowany był także sporadycznie kopolimer octanu winylowego i eteru etylowo-winylowego. Żywica ta dzięki wysokiemu ciężarowi cząsteczkowemu odznacza się twardością błony, jednocześnie jednak jej roztwory cechuje bardzo wysoka lepkość. Ma dużą adhezje do drewna i dobrą odporność na działanie mikroorganizmów ${ }^{78}$.

Najpopularniejszym spośród kopolimerów pochodnych winylowych preparatem do impregnacji był niemiecki Vinoflex MP-400 - kopolimer chlorku winylu i eteru winylowoizobutylowego. Do jego zalet należy ła-

75 B. Soldenhoff, Wrmacnianie drewna symicami termoplastycznymi, [w:] Chemia w konserwacii zabytków. Materialy z. II Ogólnopolskiego Zjazdu Chemikón Konserwatorów, Torun-Bachotek wrzesień 1981, Warszawa 1982, s. 51.

76 M. Paciorek, Badania wybranych tworsyn termoplastycznych stosowanych do impregnacïi drewna, „Studia i Materiały Wydziału Konserwacji i Restauracji Dzieł Sztuki Akademii Sztuk Pięknych w Krakowie", t. III, Kraków 1993, s. 34, 38, 87.

77 I. Płuska, Cź̨ściowe usunięcie znisz̨zonego drewna rzéźby polichromowanej i zastapienie go skorupa z. tworzyw sztucznych, „Ochrona Zabytków” 1970, nr 2, s. 101, 104; Głos autora prac został przedstawiony również w dyskusji zapisanej w: J. Rudkowski, Sesja naukowa na temat konserwacji drewna polichromowanego, „Ochrona Zabytków” 1974, nr 1, s. 77-78; Spis dokumentacji konserwatorskich zabytków ruchomych, cz. I: dla zabytków znajdujących się poza muzeami, A-N..., s. 40, 42, 50, 66, 229, 245, 257, 281; Spis dokumentacji konserwatorskich zabytkón ruchomych, cz. I: dla zabytków znajdujących się poza muzeami, O-Ż..., s. 11, 41, 85-87, 98, 112-113, 125-127, 145, 230.

78 B. Chaber, op.cit., s. 10; G. Zborowska, Rekonstrukecja obrazu tablicowego z. 96 cześsi, „Ochrona Zabytków” 1967, nr 3, s. 50. 
twa rozpuszczalność w węglowodorach aromatycznych. Błony otrzymywane po odparowaniu rozpuszczalnika są bezbarwne, przeźroczyste i maja dużą odporność na działanie wody i kwasów. Jest to żywica o dużej wytrzymałości mechanicznej. Roztwory o stężeniu w granicach $20-30 \%$ odznaczają się małą lepkością i dobrze wnikają w drewno ${ }^{79}$. Właściwości drewna nasyconego Vinoflexem MP-400, szczególnie przy zastosowaniu metody impregnacji pod zmniejszonym ciśnieniem, ulegały znacznej poprawie. Dotyczyło to przede wszystkim drewna zniszczonego w strefie powierzchniowej na skutek działania czynników atmosferycznych oraz drewna o średnim stopniu zniszczenia przez grzyby. W wyniku impregnacji osiągano znaczne zmniejszenie nasiąkliwości i higroskopijności, zwiększenie ciężaru właściwego, twardości i wytrzymałości na ściskanie ${ }^{80}$. Zastrzeżenia budzi jednak możliwość występowania w tej żywicy śladów kwasu jako resztek technologicznych i ewentualnych produktów powolnego rozkładu pod wpływem czynników atmosferycznych ${ }^{81}$. Ponadto pod wpływem światła błony tego kopolimeru żółkły i stawały się kruche oraz wydzielał się chlorowodór ${ }^{82}$.

Vinoflexu MP-400 używano masowo zarówno do impregnacji drewnianej architektury - ścian i stropów, stanowiących jednocześnie podłoże malowideł, elementów wyposażenia wnętrz kościelnych, rzeźb drewnianych, drewnianych podobrazi, zabytków rzemiosła artystycznego. Wzmiankowano także o stosowaniu roztworów tej żywicy w poszczególnych pracowniach konserwatorskich. Najczęściej wykorzystywano roztwory w toluenie, $\mathrm{w}$ toluenie $\mathrm{z}$ acetonem, rzadziej $\mathrm{w}$ toluenie $\mathrm{z}$ chlorkiem etylenu lub chlorobenzenem, w acetonie, ksylenie. Niekiedy stosowano dodatki gamek-

79 B. Chaber, op.cit., s. 10; J. Ciabach, Wtaściności symic..., s. 44; M. Czajnik, Środki..., s. 26; W. Domasłowski, Konserwacja..., s. 55; idem, Wlasności..., s. 599; A. Lisewska, „Konserwacja rzeźby drewnianej polichromowanej”, praca magisterska, Toruń 1962, s. 48 (mps przechowywany w bibliotece ZKMiRP, nr 23); W. Ślesiński, Konserwacja zabytkón sq̨uki, t. 2..., s. 22; idem, Konserwacja zabytków sұtuki, t. 3: Rz̨emiosto artystyczne, Warszawa 1995, s. 21.

${ }^{80}$ M. Czajnik, P. Rudniewski, D. Tworek, op. cit., s. 80; A. Lisewska, op.cit., s. 50; J. Ważny, Badanie wptywu impregnacji Vinoflexem MP-400 na wlaściwości techniczne drewna wystroju ręȩ́biarskiego wież, pałacu w Wilanowie, „Ochrona Zabytków” 1970, nr 2, s. 88.

81 W. Kurpik, Przemieszczanie spoin w crasie wysychania mas trocinowych, [w:] Zabytkowe drewno konserwacja i badania, Warszawa 1987, s. 117.

82 J. Ciabach, Wtaściności ṡywic..., s. 44. 
sanu $^{83}$, DDT $^{84}$, Antoxu ${ }^{85}$, pięciochlorofenolanu sodu ${ }^{86}$, eugenolu ${ }^{87}$, chloroformu $^{88}$. Bywało też, że impregnację Vinoflexem łączono w jednym obiek-

${ }^{83}$ Gameksan - sześciochlorocykloheksan $\mathrm{C}_{6} \mathrm{H}_{6} \mathrm{Cl}_{6}$. Jeden z pierwszych insektycydów. Mieszanina dziewięciu różnych izomerów aktywnych i nieaktywnych. Nierozpuszczalny w wodzie, rozpuszczalny w alkoholu, chloroformie, czterochlorku węgla. Działał długi czas niszcząc układ nerwowy insektów. Jako insektycyd przewyższał w działaniu dziewięciokrotnie DDT. Stosowano go również jako fungicyd. Jego stosowania zakazano w $1986 \mathrm{r}$. Za: S. Jędrzejewska, P. Rudniewski, A. Wawrzyńczak, op.cit., s. 85; J. Kehl, op.cit., s. 141; K. Szczepińska, op.cit., s. 34.

${ }^{84}$ DDT - dwuchlorodwufenylotrójchloroetan $\left(\mathrm{C}_{6} \mathrm{H}_{4} \mathrm{Cl}\right)_{2}-\mathrm{CH}-\mathrm{CCl}_{3}$. Insektycyd oddechowy i kontaktowy. Występuje w postaci izomerów, z których silne własności owadobójcze wykazuje izomer para-. W czystej postaci były to białe kryształy praktycznie nierozpuszczalne w wodzie, natomiast łatwo rozpuszczalne w chloroformie, acetonie, benzenie, eterze i benzynie lakowej. W postaci sproszkowanej, zawierającej 5-10\% czystego preparatu w mieszaninie z talkiem lub w 5\% roztworze w benzynie lakowej i innych rozpuszczalnikach miał zastosowanie w pracach konserwatorskich przy dezynfekcji drewna. Od 1986 roku obowiązuje zakaz stosowania tego preparatu w ochronie drewna. Za: J. Hopliński, Farby i spoiwa malarskie, Wrocław Warszawa Kraków Gdańsk Lódź 1990, s. 76, 81; S. Jędrzejewska, P. Rudniewski, A. Wawrzyńczak, op.cit., s. 81; J. Kehl, op.cit., s. 103; A. Krajewski, P. Witomski, Ocbrona drewna, Warszawa 2003, s. 226.

${ }^{85}$ Antox oparty był na bazie toksycznej pięciochlorofenolu i metoksychloru w rozpuszczalnikach alifatycznych i chlorowanych aromatycznych. Stosowano go do odgrzybiania i zwalczania owadów we wszystkich elementach i detalach drewnianych oraz do zabezpieczania drewna przed ponownym porażeniem. Do ujemnych cech tego preparatu należało podnoszenie palności drewna, a także tendencja do krystalizowania na powierzchni impregnowanego przedmiotu z chwilą odparowania rozpuszczalnika oraz rozmiękczanie warstw farb olejnych i werniksu. W roku 1986 zakazano stosowania pięciochlorofenolu ze względu na jego znaczną toksyczność w stosunku do ludzi. Wtedy to Antox został zastapiony przez Antox W o innym już składzie. Za: S. Jędrzejewska, P. Rudniewski, A. Wawrzyńczak, op.cit., s. 131; Stownik..., s. 54, 56; K. Szczepińska, op.cit., s. 34; A. Krajewski, P. Witomski, op.cit., s. 222.

86 Pięciochlorofenolan sodowy przez wiele lat stosowany był jako samodzielny środek do ochrony drewna przed sinizną i grzybami pleśniowymi oraz do dezynsekcji. Wnikał on w drewno na niewielką głębokość, a pod wpływem dwutlenku węgla przechodził w ortofenylofenol, nierozpuszczalny w wodzie. Jego stosowanie jest w Polsce obecnie zabronione. Za: S. Jędrzejewska, P. Rudniewski, A. Wawrzyńczak, op.cit., s. 131; Stownik..., s. 56; A. Krajewski, P. Witomski, op.cit., s. 222.

87 Eugenol to syntetyczny olejek goździkowy, o zbliżonych do niego właściwościach. Wymieniany jako nadający się do celów malarskich i konserwatorskich. Ze względu na właściwości antyseptyczne stosowany był jako dodatek do spoiw białkowych. Za: J. Hopliński, op.cit., s. 46-47.

${ }_{88}$ Chloroform $\mathrm{CHCl}_{3}$ - bezbarwna ciecz o charakterystycznej słodkiej woni, trudno rozpuszczalna w wodzie, łatwo w etanolu, benzynie i rozpuszczalnikach organicznych. 
cie z nasycaniem chlorowanym polichlorkiem winylu, woskiem, kalafonia, żywica epoksydową Epidian 5, szelakiem, klejem stolarskim, dyspersja polioctanu winylu, superchlorkiem winylu ${ }^{89}$.

\section{Żywice epoksydowe}

Żywice epoksydowe to polimery lub oligomery zawierające w swoich łańcuchach reaktywne ugrupowania epoksydowe. Nieutwardzone są dość dobrze rozpuszczalne w rozpuszczalnikach organicznych. Rozpuszczalność ich zależy od ciężaru cząsteczkowego. Żywice ciekłe są rozpuszczalne w toluenie, ksylenie, benzenie, acetonie, cykloheksanonie itp. Żywice o wyższym ciężarze cząsteczkowym (ciała stałe) rozpuszczają się w dowolnym stosunku w dwóch ostatnich rozpuszczalnikach, a w ograniczonej ilości w węglowodorach aromatycznych ${ }^{90}$.

Rozpuszczalnik balsamów, tłuszczów, żywic, wosków. Silny narkotyk. Pod wpływem światła w obecności tlenu rozkłada się tworząc fosgen. Za: S. Jędrzejewska, P. Rudniewski, A. Wawrzyńczak, op.cit., s. 68; J. Kehl, op.cit., s. 31.

89 M. Czajnik, P. Rudniewski, D. Tworek, op.cit., s. 80; L. Czubiel, op.cit., s. 46-48; idem, Prace konserwatorskie w województwie olsztyńskim w latach 1961-1968 (c\%: II), „Ochrona Zabytków” 1969, nr 1, s. 65; A. Kudła, Prace konserwatorskie - wojewódz̨two katowickie 1959-1972, „Ochrona Zabytków” 1973, nr 3, s. 216; M. Kurzątkowski, Prace konserwatorskie - województwo lubelskie (1958-1966), „Ochrona Zabytków” 1967, nr 4, s. 65-66; A. Lisewska, op.cit., s. 49-50; D. Lizun, Gotycka Pieta Szreńska, Styl, bistoria, problemy konserwatorskie dzieta, „Biuletyn Informacyjny Konserwatorów Dzieł Sztuki”" 2003, nr 3-4, s. 100, 102; H. Markowska, Przeniesienie malowidet ściennych w cerkwi drewnianej w Uluczu, pow. Brzozón z zastosowaniem t:w. „suchego montąu” (1962-1964). „Ochrona Zabytków” 1966, nr 3, s. 27-28; D. E. Olczak, op. cit., s. 75; Przeglad mykonanych prac przę oddziaty PKZ w II pótroczu 1966 r., „Biuletyn Informacyjny PKZ" 1967, nr 4, s. 71; Spis dokumentaci konserwatorskich zabytków ruchomych, cz. I: dla zabytków znajdujących się poza muzeami, A-N..., s. 31-35, 42, 49-52, 55, 56, 60-62, 65, 67-70, 80-81, 87-88, 90-92, 94-101, 105, 107, 109, 117-118, 120-122, 126, 129-130, 134, 137-138, 146-147, 153-154, 161, 163, 175, 180, 182, 192-193, 201, 209-210, 212, 216, 230, 238, 239, 241, 245, 248, 250, 254, 255, 257, 261, 265, 277, 280, 282-283, 289; Spis dokumentacii konserwatorskich zabytków ruchomych, cz. I: dla zabytków znajdujących się poza muzeami, O-Ż..., s. 7-9, 13, 25-26, 29, 34-35, 50, 60, 61, 65-67, 69-72, 75, 78, 83-86, 95, 99, 101, 105-107, 114-115, 117, 122, 123, 129-130, 133, 139-141, 148, 150-153, 155-157, 163-167, 176, 192, 197, 202, 210, 212, 213, 221-225, 238-240.

90 J. Ciabach, Wtaściwości śynic..., s. 69-70; W. Domasłowski, K. Powidzki, op.cit., s. 196-197; W. Domasłowski, Własności..., s. 580; S. Jędrzejewska, P. Rudniewski, A. Wawrzyń- 
Ugrupowania epoksydowe moga ulegać reakcjom polimeryzacji oraz poliaddycji do związków zawierających grupy aminowe, karboksylowe lub wodorotlenowe. Właściwość tę wykorzystano do utwardzania żywic epoksydowych przez usieciowanie. Proces prowadzi się za pomocą wielofunkcyjnych alifatycznych amin pierwszo- i drugorzędowych. Najczęściej stosuje się trójetylenoczteroaminę $\mathrm{H}_{2} \mathrm{~N}-\mathrm{CH}_{2}-\mathrm{CH}_{2}-\mathrm{NH}-\mathrm{CH}_{2}-\mathrm{CH}_{2}-\mathrm{NH}-\mathrm{CH}_{2}-\mathrm{CH}_{2}-\mathrm{NH}_{2}{ }^{1}$.

Utwardzona żywica epoksydowa nie topi się w podwyższonej temperaturze, jest nierozpuszczalna, odznacza się dużą wytrzymałością mechaniczną, odpornością na działanie niskiej temperatury, wpływów atmosferycznych i chemikaliów. Jej odporność na działanie światła i wody wzrasta w przypadku żywic lepiej usieciowanych. Ma również bardzo mały skurcz utwardzania ${ }^{92}$. Żywicom tym przypisuje się również pewną wartość grzybobójcza, grzyboochronną i zapobiegająca porażeniu przez owady. Wynika ona nie tylko z ich toksycznych właściwości, ale przede wszystkim jest skutkiem mechanicznego działania dużych ilości żywicy wprowadza-

czak, op.cit., s. 145; J. Pielichowski, A. Puszyński, Technologia tworzym sz̨tucznych, Warszawa 1992, 1994, s. 244.

91 Do utwardzania żywic epoksydowych można również stosować trzeciorzędowe aminy aromatyczne, jak dimetyloaminometylofenol, tri/dimetyloaminomeylo/fenol, addukty amonowe i poliaminoamidy oraz bezwodniki kwasów organicznych: heksachloroendometylenotetrahydroftalowego, tetrahydroftalowego lub ftalowego, których użycie wymaga jednak temperatury około $100-140^{\circ} \mathrm{C}$. Rodzaj utwardzacza na stałe wbudowującego się w powstające tworzywo, jego ilość oraz warunki utwardzania (temperatura i wilgotność powietrza lub/i materiału) mają ogromny wpływ na parametry powstającego tworzywa. Za, wraz z informacjami zawartymi w tekście: Z. Brojer, Żywice epoksydowe. Epidiany, Gliwice (1964), s. 21-22, 47-48; J. Ciabach, Wtaściwości ṡywic..., s. 73; idem, Żótknięcie symic epoksydowych, „Ochrona Zabytków”, nr 1, 1989, s. 36-38; M. Czajnik, Konserwacja drewna zabytkowego..., s. 131-132; idem, Środki..., s. 26; W. Domasłowski, K. Powidzki, op.cit., s. 197; W. Domasłowski, Wtasności..., s. 580; W. Kurpik, Utwardzanie..., s. 28; J. Pielichowski, A. Puszyński, op.cit., s. 222-224; K. Wieczorek, op.cit., s. 156-162; M. Zenkteler, Technologia klejenia drewna, Warszawa 1968, s. 284.

92 W. Domasłowski, K. Powidzki, op.cit., s. 197; W. Domasłowski, Wtasności..., s. 580; W. S. Ginell, R. Coffman, Epoxy resins - consolidated stone: appearance change on aging, „Studies in Conservation" 1998, nr 4, s. 242; P. Kozub, Badania symic epoksydowych. Badanie odporności powtok emulsji i dyspersji wodnych symic epoksydowych na dziatanie wody, „Biuletyn Informacyjny Konserwatorów Dzieł Sztuki” 2001, nr 1, s. 48; P. Stumes, The application of epoxy resins for the restoration of historic structures, „Bulletin of Association for Preservation Technology” 1971, nr 1, s. 59-63. Podaję na podstawie informacji zamieszczonych na http://www.bcin. ca (dostęp 2005.01.07). 
nych do drewna, które utrudniaja penetrację strzępek grzybni i uniemożliwiaja żerowanie larw owadzich oraz poprzez hydrofobizację drewna zmniejszają jego higroskopijność, stwarzając środowisko niekorzystne dla rozwoju szkodników ${ }^{93}$.

Żywice epoksydowe były stosowane do impregnacji zniszczonego drewna zabytkowego zarówno w czystej postaci, jak też w roztworach. W formie bezrozpuszczalnikowej cechuje je wysoka lepkość uniemożliwiająca, zwłaszcza przy stosowaniu metod bezciśnieniowych, przenikanie impregnatu w głąb drewna. Żywica wypełnia jego pory podobnie jak masa woskowo-żywiczna ${ }^{94}$. Znacznie lepsze właściwości cechują roztwory żywic epoksydowych. Mają one niską lepkość i dobrą transpirację w głąb materiałów porowatych. Lepkość roztworu nie zależy od rodzaju użytego rozpuszczalnika, najczęściej z grupy węglowodorów aromatycznych. Ponieważ maksymalny przyrost stopnia nasycenia następuje w początkowym okresie zabiegu, do impregnacji można stosować roztwory o wysokim stężeniu żywicy. Ponadto stosunkowo łatwy proces utwardzania żywic epoksydowych w strukturze drewna ogranicza niekorzystne zjawisko migracji ${ }^{95}$. Wraz ze zwiększeniem ilości rozpuszczalnika w roztworze żywicy następuje jednak pogorszenie cech otrzymywanego produktu, szczególnie zmniejszenie wskaźników wytrzymałości mechanicznej i odporności na działanie ciepła. Wynika ono z faktu ograniczenia reaktywności grupy epoksydowej

93 M. Czajnik, Badania nad zastosowaniem symic syntetycznych do zabezpieczania drewna przed rozkładem powodowanym preez, grayby, „Materiały Muzeum Budownictwa Ludowego w Sanoku” 1968, nr 8, s. 57; K. Lutomski, B. Gaida, Stan aktualny i niektóre problemy konserwacii drewna w skansenach polskich, [w:] Zabytkowe drewno konserwacja i badania, Warszawa 1987, s. 69.

94 M. Czajnik, Konserwacja drewna środkami..., s. 250; idem, Środki..., s. 250; W. Domasłowski, Konserwacja..., s. 58; idem, Własności..., s. 581; L. Kaszycka, „Konserwacja drewnianej rzeźby polichromowanej (XV w. Pieta z Kosieczyna)", praca magisterska, Zakład Technologii i Technik Malarskich Wydziału Sztuk Pięknych UMK, Toruń 1962, s. 80 (mps przechowywany w bibliotece ZKMiRP, nr 22); R. A. Munnilendam, Low..., s. 202.

95 W. Domasłowski, T. Zaremba, Badania nad ustaleniem optymalnych warunkón impregnacii drewna roztworami śywic epoksydowych, „Zeszyty Naukowe Uniwersytetu Mikołaja Kopernika w Toruniu" 1968, III, s. 224; A. Knoepfli, Restaurietung von Holz̧bauten in der Schweiz, „Deutsche Kunst und Denkmalpflege”, H. 2, 1969, s. 155-156; W. Kurpik, Przemieszczanie..., s. 123; idem, Utwardzanie..., s. 28; D. E. Olczak, op.cit., s. 53; B. Soldenhoff, Badania nad uelastycznieniem symicy Epidian 5, „Ochrona Zabytków” 1976, nr 2, s. 110; W. Ślesiński, Konserwacja zabytków sұtuki, t. 2..., s. 23; idem, Konserwacja zabytków sұ̨tuki, t. 3..., s. 21. 
i zmniejszenia tendencji do powstawania wiązań poprzecznych w strukturze utwardzanej żywicy ${ }^{96}$.

Po nasyceniu zniszczonego drewna roztworem żywicy epoksydowej zmniejszeniu ulegały jego higroskopijność, nasiąkliwość i pęcznienie objętościowe, zwiększeniu zaś wytrzymałość na ściskanie oraz twardość w kierunku stycznym i promieniowym ${ }^{97}$. W latach 70 . stwierdzono jednak, że stosowane do impregnacji żywice epoksydowe mają również wady. Zwrócono uwagę na ich kruchość, która bywa szczególnie dotkliwa w przypadku bardziej zniszczonej powierzchni drewna, najczęściej w wyniku daleko posuniętego rozkładu grzybowego. Obserwacje te nasuwały wniosek o konieczności uelastycznienia żywic epoksydowych. Za najlepszy plastyfikator uznano, należący do grupy plastyfikatorów zewnętrznych, ftalan dwubutylowy. Nie wywołuje on niekorzystnych zmian w błonach utwardzanej żywicy pod wpływem działania różnych czynników, uelastycznia żywicę i dzięki niskiej stałej dielektrycznej $(6,40)$ nie powoduje zbyt silnego pęcznienia drewna. Wadą jego jest możliwość migracji, co może z biegiem czasu doprowadzić do stopniowego zmniejszenia elastyczności żywicy, a migrujący na zewnątrz ftalan może czynić powierzchnię drewna lepką ${ }^{98}$.

Wadą impregnacji żywicami epoksydowymi jest następujące w efekcie przeprowadzonego zabiegu pociemnienie drewna, pogłębiające się w miarę upływu czasu99. Zastrzeżenia budzi też hydrolizujący wpływ na tkan-

96 Z. Brojer, op.cit., s. 16; r. A. Munnikendam, Low..., s. 203.

${ }_{97}$ M. Czajnik, Badania..., s. 57; W. Domasłowski, K. Powidzki, op.cit., s. 213-214; W. Domasłowski, Konserwacja..., s. 58-59; J. Jasieńko, Połaczenia klejowe i inżynierskie w naprawie, konserwacji $i$ wzmacnianiu zabytkowych konstrukcji drewnianych, Wrocław 2003, s. 267.

98 Żywice epoksydowe można plastyfikować przez tak zwaną plastyfikację zewnętrzną lub wewnętrzną. Plastyfikacja wewnętrzna polega na wbudowaniu w czasie procesu utwardzania w siatkę przestrzenną żywicy odpowiednich związków chemicznych zawierających grupy funkcyjne zdolne do reakcji z żywica. Do szeroko stosowanych tego typu plastyfikatorów należą: ciekłe polisiarczki, poliaminoamidy, poliestry i bezwodniki kwasowe. W tak zwanej plastyfikacji zewnętrznej dodaje się do układu złożonego z żywicy i utwardzacza substancje, które nie sa związane chemicznie. Do najczęściej używanych plastyfikatorów tego typu należy ftalan dwubutylowy. Za, wraz z informacjami zawartymi w tekście: B. Soldenhoff, Badania..., s. 110, 112.

99 W. Domasłowski, T. Zaremba, op.cit., s. 224; D. E. Olczak, op.cit., s. 53; W. Ślesiński, Konserwacja zabytkón sætuki, t. 2.., s. 23; idem, Konserwacja zabytków sætuki, t. 3..., s. 21; K. Wieczorek, op.cit., s. 96-97. 
kę drzewną stosowanych alkalicznych utwardzaczy ${ }^{100}$. W przypadku drewna polichromowanego może dochodzić także do zmian barwnych użytych pigmentów ${ }^{101}$. B. Soldenhoff stwierdziła, że wyraźnym zmianom uległy następujące pigmenty: czerwień van Dycka, błękit pruski, zielony barwnik miedziowy, żółcienie i oranże chromowe, kraplak, karmin i ultramaryna. Zmiany polegały na ciemnieniu - czernieniu lub brunatnieniu pigmentów z wyjątkiem zieleni miedziowej, która zmieniła kolor na intensywnie ciemnoniebieski ${ }^{102}$. Kolejną wadą żywic epoksydowych jest ich żółknięcie ${ }^{103}$. Następuje ono nie tylko pod wpływem światła, ale także ciepła, w temperaturze pokojowej, bez dostępu powietrza. Przyczyna tego zjawiska ma charakter wewnętrzny $\mathrm{i}$ jest związana z chemiczną naturą fenoli i ich pochodnych. W przypadku utwardzania żywic epoksydowych wieloaminami alifatycznymi bardzo ważne są warunki utwardzania. Niska temperatura i wysoka wilgotność powietrza wyraźnie sprzyjają żółknięciu ${ }^{104}$.

Żywice epoksydowe były powszechnie stosowanymi impregnatami do drewna. Nasycano nimi niepolichromowane elementy architektury drewnianej, jak też będące podobraziem malowideł ściennych, drewno sprzętów kościelnych i rzeźb oraz podobrazi obrazów malowanych na deskach, a także drewno archeologiczne i obiekty etnograficzne. Używano roztworów $\mathrm{w}$ toluenie, ksylenie, acetonie, mieszaninie toluenu $\mathrm{z}$ etanolem lub metanolem, rzadziej benzyną lakową bądź terpentyna, a niekiedy ksylenu z etanolem. Jako dodatki do roztworów wzmiankowane są Antox i nieokreślone plastyfikatory. W przypadku, gdy w jednym obiekcie stosowane były różne impregnaty wzmiankę o użyciu żywicy epoksydowej dopełniano informacja o zastosowaniu jej do najbardziej zniszczonych elementów ${ }^{105}$.

\footnotetext{
100 W. Kurpik, Przemieszrzanie..., s. 117.

101 U. Schiessl, op.cit., s. 103; W. Ślesiński, Konserwacja zabytkón sz̨tuki, t. 1..., s. 24; B. Soldenhoff, Wplyw impregnacii roztworami Epidianu 5 na zmiany barw warstw malarskich, „Ochrona Zabytków” 1975, nr 2, s. 143-144.

102 B. Soldenhoff, Wptyw..., s. 142-144.

103 J. Ciabach, Żótknięcie..., s 37; W. Domasłowski, K. Powidzki, op.cit., s. 197; D. E. Olczak, op.cit., s. 53.

104 J. Ciabach, Żótknięcie..., s. 37; W. S. Ginell, r. Coffman, op.cit., s. 242.

105 B. Chaber, op.cit., s. 12, 55-56; A. Chrzanowski, M. Nesteruk, Konserwacja drewnianych konstrukcij grodu na wagórzu zamkonym w Pultusku, „Ochrona Zabytków” 1968, nr 2, s. 127; L. Czubiel, Prace konserwatorskie w województwie olsztynskim w latach 1961-1967 (c\%. I)..., s. 47;
} 


\section{Żywice akrylowe}

Żywice akrylowe uznawane są obecnie za najbardziej odpowiadające potrzebom konserwacji. Literatura opisująca ich zastosowanie do impregnacji drewna zabytkowego podejmuje problem optymalizacji tego procesu, zwracając uwagę na stężenie żywicy, dobór rozpuszczalników, rozmieszczenie żywicy w strukturze zniszczonego drewna, migrację powrotną i odparowywanie rozpuszczalnika.

Polimery akrylowe są żywicami termoplastycznymi, niezdolnymi do współutwardzania z żywicami epoksydowymi, fenolowo-formaldehydowymi

W. Domasłowski, T. Zaremba, op. cit., s. 225, 228; T. Gentle, r. L. Barclay, G. Fairbairn, The conservation of a large exterior wood sculpture: "Sally Grant” restored, [w:] The Conservation of Wood in Painting and the Decorative Arts, Preprints of the Contributions to the Oxford Congress, 17-23 September 1978, London 1978, s. 114; M. Koller, Altars retables of the late gothic period in Austria: wood construction and conservation problems, [w:] The Conservation of Wood in Painting and the Decorative Arts, Preprints of the Contributions to the Oxford Congress, 17-23 September 1978, London 1978, s. 97; G. Kostecki, M. Paciorek, Wspótczesne konstrukcje stabilizujace podtoża oraz. metody strukturalnego wzmacniania drewna w konserwacji obrazón tablicowych, [w:] Studia i Materialy Wydziału Konserwacji $i$ Restauracji Dziet Sz̨uki Akademii Sztuk Pięknych w Krakowie, t. VI: Krakowska szkoła konserwacii w programie TEMPUS, Kraków 1996, s. 86; W. Kurpik, Niektóre zagadnienia ratowania zabytków martyrologicznych na praykktadzie wrót Rotundy w Zamościu, „Materiały Muzeum Budownictwa Ludowego w Sanoku" 1972, nr 16, s. 42; idem, Utwardzanie..., s. 28; K. Lutomski, B. Gaida, op. cit., s. 69; E. Oellermann, The working methods of the studio of Bernt Notke illustrated by the crucifix in Lübeck Cathedral, [w:] The Conservation of Wood in Painting and the Decorative Arts, Preprints of the Contributions to the Oxford Congress, 17-23 September 1978, London 1978, s. 87; D. E. Olczak, op.cit., s. 74; r. J. Orsoler, A method for the consolidation of degraded wooden carvings from the ceiling of the House of Lords, Palace of Westminster, "Journal of the Institute of Wood Science" 1983, nr 6, s. 246-253. Podaje na podstawie informacji zamieszczonych na http://www.bcin.ca (dostęp 2005.01.07); Præ̌glad..., s. 47; T. Rudkowski, Konferencja naukowa pośnięcona konserwacï wystroju drewnianego kościoła Piotra i Pawła w Krakowie, „Ochrona Zabytków” 1973, nr 2, s. 141; idem, Sesja..., s. 78; E. Schaffer, op. cit., s. 111; U. Schiessl, op.cit., s. 103; Spis dokumentacï qabytkón ruchomych, cz. I: dla zabytków znajdujących się poza muzeami, A-N..., s. 46-47, 55, 56, 84, 101, 124, 195-196, 209; Spis dokumentacï zabytkón ruchomych, cz. I: dla zabytków znajdujących się poza muzeami, O-Ż..., s. 7, 11, 15, 42, 45, 107, 108, 115, 118, 122, 126, 132, 164, 172, 208209, 214, 215, 230; K. Wieczorek, op. cit., s. 97; J. Wziątek, „Portret Filipa Melanchtona - konserwacja i zagadnienia autorstwa". Praca magisterska wykonana w katedrze Technologii i Technik Malarskich UMK, Toruń 1967, s. 60, 70-71 (mps przechowywany w bibliotece ZKMiRP, nr inw. 33). 
bądź innymi. Charakteryzują się one wieloma cennymi właściwościami: są bezbarwne, przejrzyste, wykazują dobrą adhezje do podłoża, maja wysokie parametry mechaniczne, sa wyjattkowo odporne na działanie temperatury, promieniowania UV, kwasów i alkaliów, są odwracalne, obojętne chemicznie, nierozpuszczalne w wodzie, łatwo rozpuszczalne w rozpuszczalnikach organicznych: węglowodorach aromatycznych, chlorowanych węglowodorach, estrach, ketonach, alkoholo-estrach i etero-estrach. Cechuje je lepsza niż w przypadku wielu innych polimerów termoplastycznych odporność na działanie światła, wilgoci i mikroorganizmów. Współczynnik załamania światła dla żywic akrylowych zawiera się między 1,4 a $1,5^{106}$.

Żywice tej grupy pod wpływem działania mikroorganizmów, promieniowania UV lub też oddziaływania mechanicznego ulegaja starzeniu. Procesy te powoduja zmiany cech fizycznych i mechanicznych tworzyw. Sprzyja im obecność wiązań nienasyconych, wiązań nietrwałych, na przykład estrowych oraz łatwo odrywających się od szkieletu grup i atomów ${ }^{107}$. Poliakrylany pod wpływem promieniowania UV maja większą skłonność do sieciowania, a polimetakrylany (metylu, etylu i propylu) ulegają degradacji108.

106 Polimery akrylowe i metakrylowe otrzymuje się przez polimeryzację estrów kwasu akrylowego $\mathrm{CH}_{2}=\mathrm{CH}-\mathrm{COOH}$ i metakrylowego $\mathrm{CH}_{2}=\mathrm{C}\left(\mathrm{CH}_{3}\right)-\mathrm{COOH}$. Poliakrylany należą do polimerów miękkich, natomiast polimetakrylany moga być twarde lub miękkie, w zależności od wielkości podstawnika w grupie estrowej. Właściwości polimerów warunkują przede wszystkim dwa czynniki: budowa merów i ich wzajemny stosunek ilościowy. Dobór rodzaju i ilości komonomerów oraz odpowiednie warunki reakcji pozwalaja na ksztaltowanie wielkości kopolimeru, jego elastyczności, rozpuszczalności, adhezji i zachowania pod wpływem światła. Za, wraz z informacjami zawartymi w tekście: J. Ciabach, Właściwości żymic..., s. 55; W. Domasłowski, Wtasności..., s. 585-586; C. V. Horie, Materials..., s. 103; V. Kyzelytė, op.cit., s. 47; A. I. Lazariew, M. F. Sorokin, op.cit., s. 258; M. Matuszczyk, „Retusze na malowidłach ściennych z wykorzystaniem wybranych spoiw akrylowych”. Praca magisterska napisana pod kierunkiem prof. dr. Marii Roznerskiej i mgr Ewy Roznerskiej-Świerczewskiej, Zakład Konserwacji Malarstwa i Rzeźby polichromowanej UMK, Toruń 1997, s. 33 (mps przechowywany w bibliotece ZKMiRP, nr 195); J. Pielichowski, A. Puszyński, op.cit., s. 122-123.

107 M. Paciorek, M. Rogóż, Okerélenie odporności pewnych tworzyw termoplastycznych prazy zastosowaniu metody spektrofotometrii absorpcyjnej w podczerwieni, [w:] Chemia w konserwacji zabytków. Materiaty z. II Ogólnopolskiego Zjazdu Chemików Konserwatorów, Toruń-Bachotek, wrzesień 1981, Warszawa 1982, s. 57.

108 M. Matuszczyk, Retusz̧e..., s. 35-36. 
Polimetakrylan metylu otrzymuje się w wyniku rodnikowej polimeryzacji metakrylanu metylu metodą blokowa, suspensyjna, emulsyjna lub w roztworze ${ }^{109}$. Polimer ten wyróżnia się spośród innych tworzyw dobrą odpornością na działanie czynników atmosferycznych, niskiej temperatury, roztworów kwasów, zasad i soli oraz dużą przepuszczalnością światła widzialnego i promieni nadfioletowych. Jest to żywica bezbarwna, wśród żywic metakrylowych i akrylowych ma największą twardość i wytrzymałość mechaniczną, natomiast najmniejszą elastyczność. Rozpuszczalność polimetakrylanu metylu uzależniona jest od stopnia jego polimeryzacji. Polimer o niskim ciężarze cząsteczkowym tworzy roztwory o stosunkowo niewysokiej lepkości i rozpuszcza się dobrze w chlorowanych węglowodorach alifatycznych, aromatycznych oraz w estrach i ketonach. Do typowych nierozpuszczalników należą alkohole i węglowodory alifatyczne. Daje powłoki bezbarwne, przeźroczyste ale kruche i bardzo podatne na ścieranie. Stosowany jako impregnat $\mathrm{w}$ roztworach, dzięki swej bezbarwności, jedynie w niewielkim stopniu zmienia zabarwienie impregnowanego drewna, nadając mu jednocześnie znaczną twardość i uodparniając na działanie czynników atmosferycznych i mikroorganizmów ${ }^{110}$. Przypuszcza się, że właściwości grzyboochronne polimetakrylanu metylu wynikają w niewielkim stopniu z jego trującego działania, ale przede wszystkim polegają na hydrofobizacji ścianek komórkowych drewna ${ }^{111}$. Pod wpływem światła polimer ten nie żółknie i nie sieciuje, natomiast zachodzi jego degradacja prowadząca do pękania łańcucha głównego, co powoduje obniżenie średniej

\footnotetext{
109 J. Pielichowski, A. Puszyński, op.cit., s. 120.

110 J. Ciabach, Wtaściwości śywic..., s. 56-57; M. Czajnik, Środki..., s. 26; W. Domasłowski, Badania nad strukturalnym w₹macnianiem wapienia pińczowskiego termoplastycznymi symicami sztucznymi, część II: Badania nad zastosowaniem symicy Paraloid B-72 oraz polimetakrylanu metylu, „AUNC. Zabytkoznawstwo i Konserwatorstwo” 1979, VIII, s. 5; idem, Konserwacja..., s. 54; idem, Wtasności..., s. 586; W. Kurpik, Ekstrakcja..., s. 72; J. Pielichowski, A. Puszyński, op. cit., s. 120-121; B. Slánský, Technika malarstwa, t. 2: Badanie i konserwowanie obrazón, Warszawa 1965, s. 185; J. Stachera, ,Techniki wykonania oraz metody konserwacji i restauracji powierzchni srebrzonych i lakierowanych w rzeźbie drewnianej polichromowanej", Rozprawa doktorska. Promotor prof. dr Bogumiła Rouba, Uniwersytet Mikołaja Kopernika w Toruniu, Wydział Sztuk Pięknych Instytut Zabytkoznawstwa i Konserwatorstwa, Toruń 2003, s. 108 (egzemplarz pracy autora); W. Ślesiński, Konserwacja zabytkón squtuki, t. 1..., s. 24, idem, Konserwacja zabytkón sæ̨tuki, t. 2..., s. 22-23.
}

111 M. Czajnik, Badania..., s. 57. 
masy cząsteczkowej i rozpad łańcucha bocznego ${ }^{112}$. Kopolimerami metakrylanu metylu są Paraloid B-44 i Acryloid B-44S ${ }^{113}$.

Polimetakrylan metylu stosowany był w praktyce konserwatorskiej do impregnacji obrazów, rzeźb i ołtarzy, elementów ścian i stropów, wymieniany jest też jako używany w poszczególnych pracowniach konserwatorskich. $\mathrm{Na}$ przełomie lat 50. i 60 . jako dodatek do roztworów impregnacyjnych pojawiał się popularnie wówczas stosowany gameksan ${ }^{114}$.

Podobnymi zaletami jak polimetakrylan metylu odznacza się polimetakrylan butylu. Otrzymywany jest w wyniku polimeryzacji rodnikowej metakrylanu butylu. Dzięki niskiej temperaturze zeszklenia $\left(19^{\circ} \mathrm{C}\right)$ jest to żywica miękka i elastyczna. Polimetakrylan butylu rozpuszcza się w węglowodorach alifatycznych i aromatycznych, chlorowcopochodnych węglowodorów alifatycznych, w estrach, ketonach i niektórych eterach. Nie rozpuszcza się w metanolu i etanolu, w glikolu etylenowym i glicerynie, w acetonitrylu i w dwuchloroformamidzie. Rozpuszczalność w benzynie lakowej zależy od stopnia polimeryzacji. Gatunki o niskim stopniu polimeryzacji rozpuszczają się całkowicie, o wysokim tylko częściowo. Miesza się z nitrocelulozą i niektórymi kopolimerami chlorku winylu. Nie miesza się z octanem celulozy, metylo- i etyloceluloza, damarą i szelakiem. Pod wpływem promieniowania nadfioletowego sieciuje bez wydzielenia produktów lotnych i żółknie.

Poza żywicami otrzymywanymi z polimetakrylanu n-butylu znane sa również produkty polimeryzacji jego izomeru, metakrylanu izo-butylu. Są to żywice nieco twardsze, nieco mniej elastyczne, mniej podatne na brudzenie, tworzące powłoki o większej odporności na działanie wody. Tempera-

112 A. Charlesby, Chemia radiacyjna polimerón, Warszawa 1962, s. 316; J. Ciabach, W taściwości symwic..., s. 57; A. Kamińska, Wplyw masy czasteczkowej i polimolekularności polimerów na ich wtaściności fizyczne i mechaniczne oraz, na odporność na dzৃiatanie UV, Toruń 1975, s. 47; J. Stachera, op. cit., s. 108.

113 J. Ciabach, Nowe polimery na pótkach skelepowych, „Biuletyn Informacyjny Konserwatorów Dzieł Sztuki” 1991, nr 2, s. 2; J. Stachera, op.cit., s. 106.

114 L. Kaszycka, op. cit., s. 80; J. Prosnakowa, M. Puciata, Prace konserwatorskie w drewnianym kościele parafialnym w Bogussycach koto Rany Mazowieckiej, „Ochrona Zabytków” 1961, nr 3-4, s. 65-66; J. Rudkowski, Sesja..., s. 77; Spis dokumentacji zabytków ruchomych, cz. I: dla zabytków znajdujących się poza muzeami, A-N..., s. 50, 53, 89, 120, 130-131, 140, 141, 155, 159, 176, 282; Spis dokumentacji zabytków ruchomych, cz. I: dla zabytków znajdujących się poza muzeami, O-Ż..., s. 18, 43, 75, 100, 101, 130, 135, 136-137, 161, 172, 179, 208. 
tura zeszklenia polimetakrylanu izo-butylu wynosi około $50^{\circ} \mathrm{C}$. Rozpuszcza się on w benzynie lakowej, w węglowodorach aromatycznych, w estrach, ketonach i eterach glikolu etylenowego. Latwiej niż polimetakrylan n-butylu ulega sieciowaniu, jednak postępującej w miarę upływu czasu utracie rozpuszczalności nie towarzyszy żółknięcie ani wydzielanie się produktów lotnych ${ }^{115}$. Produktami handlowymi na bazie polimetakrylanu butylu sa $\mathrm{Pa}$ raloid B-67, Plexigum P28, Plexugum PQ 610

Roztwory żywic na bazie obu izomerów znalazły zastosowanie do impregnacji drewna zabytkowego ${ }^{117}$.

115 J. Ciabach, Badania dotyczqce..., s. 78-79; idem, Badania nad..., s. 44; idem, Starzenie sie werniksu Van Gogh S.3 pod wplywem promieniowania nadfioletowego, „AUNC. Zabytkoznawstwo i Konserwatorstwo" 1993, XX, s. 119-120; idem, Wtaściwości i aastosowanie ajymic otraymywanych ₹. metakrylanu butylu, „Ochrona Zabytków” 1984, nr 3, s. 206-208; idem, Wtaściwości jymic..., s. 57-59; M. Czajnik, Środki..., s. 26; W. Domasłowski, Konserwacja..., s. 54; idem, Własności..., s. 586; K. A. Krzyżyński, op.cit., s. 24; V. Kyzelyté, op.cit., s. 66; D. E. Olczak, op. cit., s. 54; K. Sibul, Materials Used in Conservation of Painted Wooden Objects in Estonia, [w:] Materialy z konferencji ARIADNE NR 10, Praga 22-28.04.2002, s. 4; W. Ślesiński, Konserwacja zabytków sætuki, t. 2.., s. 23; E. De Witte, Resins in conservation: introduction to their properties and application, [w:] The proceedings of the symposium Resins in conservation beld at the University of Edinburgh 21tit-22nd May 1982, Edinburgh 1988, s. 1-5.

116 Paraloid B-67, produkt amerykańskiej firmy Rohm and Haas, jest dostępny w handlu w postaci 100\% żywicy w formie granulek. Jest bezbarwny, przeźroczysty, termoplastyczny, jego temperatura zeszklenia wynosi około $50^{\circ} \mathrm{C}$. Bardzo dobrze rozpuszcza się w benzynie lakowej i terpentynie, która jednak znacząco wpływa na jego żółknięcie i podnosi tendencję żywicy do sieciowania oraz w węglowodorach alifatycznych i aromatycznych, eterach, estrach, alkoholach, eterach glikolu etylenowego. Plexigum PQ 610 i Plexigum P28, produkcji niemieckiej firmy Roehm GmbH, są europejskimi odpowiednikami Paraloidu B-67. Plexigum PQ 610 jest żywicą bezbarwna, przeźroczysta, termoplastyczna, o temperaturze zeszklenia około $50^{\circ} \mathrm{C}$. W handlu jest dostępne w postaci $100 \%$ żywicy w formie granulatu. Rozpuszcza się w benzynie lakowej, węglowodorach aromatycznych, estrach, ketonach, eterach glikolu etylenowego. Za: J. Ciabach, Nazny bandlowe symic sztučnych, „Biuletyn Informacyjny Konserwatorów Dzieł Sztuki”, nr 3, 1991, s. 4; idem, Nowe..., s. 2; C. Hulmer, Notes on the Formulation and Application of Acrylic Coating, [w:] Conservation and Restoration of Pictoral Art, Edited by N. Bromelle and Perry Smith, London-Boston 1976, s. 146; V. Kyzelyte, op.cit., s. 63, 65; J. Stachera, op.cit., s. 106.

117 J. Ciabach, Wtaściności ṡymic..., s. 58; U. Bieszczad, op.cit., s. 10; W. Domasłowski, Wtasności..., s. 586; D. E. Olczak, op.cit., s. 53; K. Sibul, op.cit., s. 3; B. Slánský, Technikea malarstwa, t. 1..., s. 104; B. Slánský, Technika malarstwa, t. 2..., s. 185; W. Ślesiński, Konserwacja zabytkón squtuki, t. 1..., s. 23; idem, Konserwacja zabytkón sz̨tuki, t. 2.., s. 23; Spis dokumentacji zabytkón ruchomych, cz. I: dla zabytków znajdujących się poza muzeami, A-N..., 
Metakrylan butylu łatwo ulega wspólnej polimeryzacji lub kopolimeryzacji z innymi monomerami. Otrzymywane w ten sposób żywice sa termoplastyczne, rozpuszczalne w cieczach organicznych. Charakteryzuje je duża elastyczność i mała chłonność wody, dobra odporność na działanie mikroorganizmów ${ }^{118}$.

Kopolimeryzacja metakrylanu butylu z metakrylanem metylu daje żywice twardsze, o mniejszej kurzochłonności i większej odporności na sieciowanie. Rozpuszczają się one gorzej w benzynie lakowej, ale ich rozpuszczalność w węglowodorach aromatycznych, estrach i ketonach nie odbiega zasadniczo od rozpuszczalności polimetakrylanu butylu.

Do grupy kopolimerów metakrykanów butylu i metylu otrzymywanych na drodze ich wspólnej polimeryzacji w roztworze toluenowym należał także produkowany w Polsce Osolan K (stosunek metakrylanu metylu do metakrylanu butylu wynosił 1:3) oraz Osolan K16. Stężenie roztworu Osolanu $\mathrm{K}$ występującego w handlu wynosiło 7-9\%, lepkość $4 \mathrm{mPas}$. Pod wpływem UV nie żółknie i sieciuje wolniej niż wiele innych żywic tego typu, bez wydzielenia produktów lotnych ${ }^{119}$. Żywicę tą badał M. Paciorek, porównując ją do Winacetu R-50, Paraloidu B-72 i Osolanu KL. Stwierdził, że powoduje ona najwyższy wzrost wytrzymałości drewna, jednak jej błony są twarde, o małym stopniu elastyczności. Analizując rozmieszczenie tworzywa w drewnie, autor ten uzyskał lepsze wyniki w przypadku roztworów 10\% niż 20\%, zarówno w warunkach normalnego, jak i opóźnionego odparowywania rozpuszczalnika ${ }^{120}$. Osolan K16 jest około $48 \%$ roztworem w toluenie. Jest to bezbarwna, przezroczysta, syropowata ciecz. Do impregnacji stosowany był po rozcieńczeniu do odpowiedniego stężenia ksylenem, toluenem, benzyną lakową ${ }^{121}$.

s. 182-183; Spis dokumentacii zabytkón ruchomych, cz. I: dla zabytków znajdujących się poza muzeami, O-Ż..., s 79.

118 J. Ciabach, Wtaściwości $i$ zastosowanie symic otraymywanych..., s. 209; idem, Wtaściwości ìywic..., s. 58 .

119 J. Ciabach, Wtaściwości $i$ zastosowanie symic otraymywanych..., s. 208; idem, Badania nad..., s. 42, 48; idem, Narmy..., s. 4; M. Paciorek, Badania..., s. 22; J. Stachera, op.cit., s. 110.

120 M. Paciorek, Badania..., s. 87.

121 K. Wieczorek, op.cit., s. 87. 
Znajdował zastosowanie miedzy innymi do impregnacji wzmacniającej drewna zabytkowego ${ }^{122}$.

Druga ważna grupę kopolimerów metakrylanu butylu stanowia produkty jego wspólnej polimeryzacji z niewielką ilością (od 1 do 5\%) kwasu metakrylowego. Dzięki obecności kwasu w makrocząsteczce występuja wolne grupy karboksylowe wydatnie zwiększające przyczepność żywicy do innych, szczególnie nieorganicznych materiałów. Powstaje żywica miękka, charakteryzująca się małą chłonnością wody, dobrą odpornością na działanie mikroorganizmów. Wadą jej jest brak odporności na działanie promieniowania nadfioletowego, pod którego wpływem polimer ten łatwo ulega sieciowaniu. Produktem handlowym jest Osolan K1, stosowany między innymi do wzmacniania drewna zabytkowego ${ }^{123}$.

Osolan KL był również kopolimerem metakrylanu n-butylu z kwasem metakrylowym ${ }^{124}$, rozpuszczonym w octanie etylu, o stężeniu roztworu wynoszącym około 50\%. Jego liczba kwasowa wynosi 10-18 mg KOH/g. Kopolimer ten charakteryzuje się, ze względu na obecność w łańcuchu grup karboksylowych, bardzo dobrą adhezją do szkła, drewna, skóry, tkanin, betonu i tworzyw sztucznych. Pod wpływem promieniowania UV zachodzi sieciowanie żywicy bez jednoczesnego rozkładu na produkty lotne ${ }^{125}$. Przygotowanie roztworu impregnacyjnego polegało na rozcieńczeniu produktu handlowego do stężenia 10-20\% za pomoca rozpuszczalników z grupy estrów, ketonów lub węglowodorów aromatycznych ${ }^{126}$. Drewno nasycone Osolanem KL wykazuje niższą higroskopijność i nasiąkliwość niż analo-

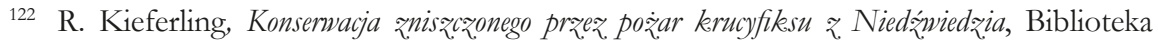
Muzealnictwa i Ochrony Zabytków, ser. B, t. 88, 1992, s. 292; D. E. Olczak, op. cit., s. 74.

123 J. Ciabach, Wtaściwości i zastosowanie symic otrzymywanych..., s. 208; idem, Wtaściwości isywic..., s. 58; M. Kiepuszewska, M. Roznerska, Próba identyfikacji substancji wæ̌macniajacych drewno pray usyciu zapisu rentgenograficznego, „AUNC. Zabytkoznawstwo i Konserwatorstwo”, XX, 1993, s. 152; W. Kozak, Szeptocki ikonostas. Konserwacja ikonostasu w cerkwi Archikatedralnej w Przemyślu, „Biuletyn Informacyjny Konserwatorów Dzieł Sztuki” 2000, nr 2, s. 33; K. Sibul, op.cit., s. 3.

124 Inny skład Osolanu KL podają K. Wieczorek i M. Paciorek, według których jest to $50 \%$ roztwór polimetakrylanu butylu w octanie etylu. Por.: M. Paciorek, Badania..., s. 22; K. Wieczorek, op.cit., s. 90.

125 J. Ciabach, Badania nad..., s. 42, 46; idem, Nazwy..., s. 4; M. Paciorek, M. Rogóż, op.cit., s. 57; J. Pielichowski, A. Puszyński, op.cit., s. 123; J. Stachera, op.cit., s. 110.

126 K. Wieczorek, op.cit., s. 90. 
giczne próby wykonane z Paraloidem i Movilithem. Wynika to z niskiej masy cząsteczkowej tej żywicy, pozwalającej na jej wnikanie w większą liczbę porów. Poza tym Osolan KL tworzy błony o bardzo niskiej higroskopijności ${ }^{127}$. M. Paciorek stwierdził ponadto, że błony Osolanu KL cechuje odpowiednia elastyczność i wytrzymałość mechaniczna. Do impregnacji drewna autor ten poleca, ze względu na równomierność rozmieszczenia tworzywa w drewnie, roztwory $20 \%{ }^{128}$. Żywica ta znalazła zastosowanie w praktyce konserwatorskiej ${ }^{129}$.

Producentem Osolanów były Zakłady Chemiczne w Oświęcimiu.

Kopolimerem akrylowym najszerzej stosowanym w konserwacji zabytków jest Paraloid B-72. Jest to kopolimer metakrylanu etylu (70\%) i akrylanu metylu (30\%), produkowany przez amerykańską firmę Rohm and Haas. Rozpuszcza się w wielu cieczach organicznych, takich jak węglowodory aromatyczne, chlorowcopochodne węglowodorów alifatycznych i aromatycznych, estry, ketony i etery, między innymi etery glikolu etylenowego i propylenowego i ich estry. Daje roztwory o stosunkowo niedużej lepkości. Nie rozpuszcza się w węglowodorach alifatycznych. W 96\% alkoholu etylowym rozpuszcza się powoli, dając lekko mętne roztwory, jednak po wyschnięciu powstaja z nich przeźroczyste, spójne filmy. Miesza się z żywicami winylowymi, estrami celulozy, niektórymi żywicami silikonowymi i typowymi zmiękczaczami (ftalan dwubutylowy, sebacynian dwuoktylowy). J. Ciabach podaje za Mitanovem i Todorovem, że miesza się także z Cosmoloidem $80 \mathrm{H}$ i damara. Stopień polimeryzacji Paraloidu B-72 wynosi około 900 , a temperatura zeszklenia $40^{\circ} \mathrm{C}$. W temperaturze $70-75^{\circ} \mathrm{C}$ mięknie, a w temperaturze $145-150^{\circ} \mathrm{C}$ uplastycznia się (płynie). Paraloid B-72 uznawany jest za jedną z żywic najbardziej odpornych na działanie światła. Powszechnie uważa się, że żywica ta nie żółknie i nie traci rozpuszczalności w cieczach organicznych przez czas znacznie dłuższy niż inne żywice

127 B. Soldenhoff, Wzmacnianie drewna roztworami symic termoplastycznych, „AUNC. Zabytkoznawstwo i Konserwatorstwo" 1987, XI, s. 95, 97.

128 M. Paciorek, Badania..., s 34, 87.

129 D. E. Olczak, op.cit., s. 73-74; J. Wyszyńska, Konserwacja obrazu „Matka Boska z Drieciatkiem w ogrodżie różanym”, „Biblioteka Muzealnictwa i Ochrony Zabytków” 1992, seria B, t. 88, s. 229; eadem, Konserwacja obrazu "Matka Boska z. Dizieciatkiem w ogrodzie różanym”, „Ochrona Zabytków” 1992, nr 3, s. 175. 
napromieniane $\mathrm{w}$ tych samych warunkach, nie stwierdzono też powstawania nierozpuszczalnego żelu. Żywica ta, właśnie ze względu na swą dużą trwałość, należy do klasy A, według klasyfikacji czasu przydatności polimerów stosowanych w konserwacji, sporządzonej przez Fellera. Kopolimer ten cechuje ponadto dobra odporność na działanie wody, alkoholi, kwasów i tłuszczów. Tworzy powłoki o średniej odporności na zabrudzenie. Jest bardziej elastyczny od polimetakrylanu metylu, a mniej od polimetakrylanu butylu. Stosuje się go między innymi do strukturalnego wzmacniania materiałów porowatych jako klej oraz jako środek do wytwarzania powłok ochronnych ${ }^{130}$. Impregnacja roztworami tego preparatu pozwala na podnie-

${ }^{130}$ Adhesives..., s. 116; S. M. Blackshaw, S. E. Ward, Simple tests for assessing materials for use in conservation, [w:] The proceedings of the symposium Resins in conservation beld at the University of Edinburgh 21t-22nd May 1982, Edinburgh 1988, s. 2-11; P. Buksalewicz, M. Gajdziński, K. Lutomski, op.cit., s. 111; S. M. Carlson, A. P. Schniewind, op.cit., s. 26-32; J. Ciabach, Badania dotyczace..., s. 79-80; idem, Badania nad..., s. 43; idem, Investigation of the cross-linking of thermoplastic resins effected by ultraviolet radiation, [w:] The proceedings of the symposium Resins in

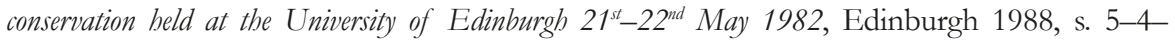
5-8; idem, Nazwy..., s. 4, idem, Wtaściwości i zastosowanie Paraloidu B-72, „Ochrona Zabytków” 1982, nr 1-2, s. 111-112; idem, Wtaściwości àywic..., s. 59; E. De Witte, A. Terfve, op. cit., s. 17; W. Domasłowski, Badania..., op. cit., s. 4-5; r. L. Feller, Problems in the Investigation of Picture Varnishes, [w:] Conservation and Restoration of Pictoral Art, London-BostonSydney-Wellington-Durban-Toronto 1978, s. 144; idem, The Relative Solvent Power Needed to Remove Various Aged Solvent-Type Coatings, [w:] Conservation and Restoration of Pictoral Art, s. 159; C. V. Horie, Materials..., s. 31, 106; D. Horton-James, S. Walstone, S. Zounis, Evaluation of the stability, appearance and performance of resins for the adhesion of flacking paint on ethnographic objects, „Studies in Conservation” 1991, nr 4, s. 217-218; J. Jakubiak, M. Nowakowska, Porównanie własności Paraloidu B-72 i Paraloidu B-82, „Biuletyn Informacyjny Konserwatorów Dzieł Sztuki” 1996, nr 3-4, s. 31-32; M. Kiepuszewska, M. Roznerska, op.cit., s. 152; M. Koller, Gothic retables in Austria. 150 years of restoration and conditions, [w:] Retables in situ. Conservation \& restoration. 11'sjournées d'études de la section française de l'institut international de conservation, Roubaix, 24-25 Juin 2004, Paris 2004, s. 37; V. Kyzelyte, op.cit., s. 48, 62; M. Makowska, „Problemy konserwacji i restauracji rzeźby drewnianej polichromowanej na przykładzie krucyfiksu z Izbicy Kujawskiej”, Praca magisterska napisana w Zakładzie Konserwacji Malarstwa i Rzeźby Polichromowanej Instytutu Zabytkoznawstwa i Konserwatorstwa UMK w Toruniu pod kierunkiem doc. dr hab. Marii Roznerskiej, s. 54-55 (mps przechowywany w bibliotece ZKMiRP, nr 116); M. Matuszczyk, op. cit., s. 58; idem, Rozpuszczalniki Paraloidu B-72, Acta Universitatis Nicolai Copernici, Zabytkoznawstwo i Konserwatorstwo, XXX, 1998, s. 253; H. Michaelson, Restaurierung eines intarsierten Prunktisches von Johann Daniel Sommer, „Neue Museumskunde. Theorie und Praxis der Museumarbeit” 1978, nr 2, s. 129; M. Paciorek, Badania..., s. 22; A. P. Schniewind, What goes up must come down...But is it reversible?, Preprints of papers presented at the fifteenth annual meeting of 
sienie parametrów wytrzymałościowych. Drewno nasycone Paraloidem B-72 nie wykazuje ponadto zmian struktury przestrzennej - żywica nie wypełnia wnętrz naczyń i cewek ${ }^{131}$. Analizując rozmieszczenie żywicy w drewnie M. Paciorek najkorzystniejsze wyniki uzyskał przy zastosowaniu roztworu $20 \%$, stwarzając warunki opóźnionego odparowywania rozpuszczalnika ${ }^{132}$.

O powszechności stosowania roztworów tego kopolimeru w zabiegach impregnacji wzmacniającej drewna świadczą bardzo liczne wzmianki na ten temat zawarte w literaturze. Obejmują one zarówno rzeźby drewniane, jak i wyposażenie kościołów ${ }^{133}$, gdzie autorzy wskazują również na kłopoty na-

the American Institute for Conservation of Historic and Artistic Works, Vancouver, British Columbia, Canada, May 20-24, 1987, s. 107-117. Podaję na podstawie informacji zawartych na http://www.bcin.ca (dostęp 2005.01.05); M. Serck-Dewaide, Disinfestation and consolidation of polychromed wood at the Institut Royal du Patrimoine Artistique Brussels, [w:] Conservation of Wood in Painting and the Decorative Arts, Preprints of the Contributions to the Oxford Congress, 17-23 September 1978, London 1978, s. 82; J. Stachera, op.cit., s. 106-107; I. Swaczyna, op.cit., s. 64-65; W. Ślesiński, Konserwacja zabytkón štuki, t. 1..., s. 23; idem, Konserwacja za-

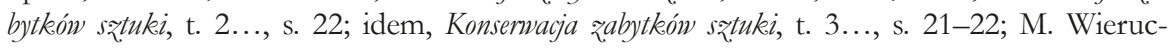
ka, op.cit., s. 31-32; E. De Witte, op.cit., s. 1-3-1-5.

131 P. Buksalewicz, M. Gajdziński, K. Lutomski, op.cit., s. 112; M. Makowska, op.cit., s. 59; M. Paciorek, Badania..., s. 34, 38.

132 M. Paciorek, Badania..., s. 87.

133 B. Aleksiejew-Wantuch, Konserwacja rzę́by drewnianej polichromowanej Najswiętsza Panna Maria z. Drieciatkiem z okolic Kalisz̧, datowanej na pierwszq ćnierć XVI wieku, ze zbiorów Muzeum Narodowego w Krakowie, [w:] Studia i Materialy Wydziatu Konserwacji $i$ Restauracji Dziet Sztuki Akademii Sztuk Pieknych w Krakowie, t. VIII: Nowe pokolenie konserwatorów krakowskich, Kraków 1998, s. 134; U. Bieszczad, Wymiana znisz̨zonego drewna rzeźby polichromowanej na pianke poliuretanowa, Praca magisterska pod kierunkiem dr Bożeny Soldenhoff wykonana w Zakładzie Konserwacji Malarstwa i Rzeźby Polichromowanej Instytutu Zabytkoznawstwa i Konserwatorstwa, Toruń 1982, s. 46-47 (mps przechowywany w bibliotece ZKMiRP, nr 102); A. Kłosowska, Mumie zbożowe ₹. Muzeum Archeologičnego w Krakowie - konserwacja $i$ badania technologiczne, [w:] Studia i Materiaty Wydziatu Konserwacji i Restauracji Dziet Sztuki Akademii Sz̨uk Pięknych w Krakowie, t. VIII: Nowe pokolenie konserwatorów krakowskich, s. 154; S. Lagoda, „Problem impregnacji (konserwacji) oraz estetycznego opracowania (restauracji) dwóch rzeźb (barokowej i gotyckiej) drewnianych polichromowanych z muzeum ze Szczecina i Olsztyna", Praca magisterska napisana pod kierunkiem prof. dr Marii Roznerskiej w Zakładzie Konserwacji Malarstwa i Rzeźby Polichromowanej, Toruń 1997, s. 38, 40-41 (mps przechowywany w bibliotece ZKMiRP, nr 224); M. Makowska, op.cit., s. 55; J. Młodożeniec, Zastosowanie rentgenowskiej tomografii komputerowej w badaniach struktury drewna $i$ drewnianej rzę́by polichromowanej, „Ochrona Zabytków”, nr 2, 1996, s. 175; S. M. Nakhla, op.cit., s. 38, 41-43; M. Niedzielska, Konserwacja rzę́by „Król Każimierz. Wielki” z. Muzeum UJ, „Biblioteka Muzealnictwa i Ochrony Zabytków" 1992, seria B, t. 88, 1992, s. 285; eadem, Konserwacja ręé́by „Król Ką̧imierr. Wielki” z Muẓeum UJ, „Ochrona Zabytków” 1992, nr 3, s. 225-131; 
potykane w trakcie prac przy obiektach o znacznych rozmiarach, dotyczące powrotnej migracji roztworów i długiego czasu odparowywania rozpuszczalnika ${ }^{134}$, a także malarstwa tablicowego i ściennego na podłożu drewnianym $^{135}$ oraz zabytkowych sprzętów użytkowych ${ }^{136}$.

J. Rudkowski, Sesja..., s. 78 - wypowiedź mgr Marty Żurowskiej (PKZ Kraków); M. Sawczuk, Konserwacja i badania technologiczne manierystycznej ržeźby Chrystus Ukrzyżowany z klasz̧toru oo. Dominikanów w Krakowie, [w:] Studia i Materialy Wydziatu Konserwacji $i$ Restauracji Driet Sztuki Akademii Sztuk Pieknych w Krakowie, t. VIII: Nowe pokolenie konserwatorów krakowskich, s. 143; M. Serck-Dewaide, op. cit., s. 82; Spis dokumentacï konserwatorskich zabytków ruchomych, cz. I: dla zabytków znajdujących się poza muzeami, A-N..., s. 84; Spis dokumentacji konserwatorskich zabytków ruchomych, cz. I: dla zabytków znajdujących się poza muzeami, O-Ż..., s. 128-129, 148-149.

134 Por.: zapis dyskusji zawarty w: J. Rudkowski, Konferencja..., s. 143; M. Serck-Dewaide, op. cit., s. 81 .

135 J. Bursze, G. Lipkowa, Udziat polskich konserwatorów w ratowaniu zabytków Florencji, „Ochrona Zabytków” 1968, nr 3, s. 85; N. Goetghebeur, The treatment of panels at the Institute Royal du Patrimoine Artistique, Brussels, [w: Conservation of Wood in Painting and the Decoratove Arts, Preprints of the Contributions to the Oxford Congress, 17-23 September 1978, London 1978, s. 167; A. Karwowska, Historia, ikonografia i konserwacja epitafjnego(?) obrazu tablicowego z. XVI wieku, „Biuletyn Informacyjny Konserwatorów Dzieł Sztuki” 2003, nr 3-4, s. 29; G. Kostecki, Konserwacja obrazu „Madonna ₹. Drieciatkiem i szczygietkiem”, „Biblioteka Muzealnictwa i Ochrony Zabytków" 1992, seria B, t. 88, s. 248; G. Kostecki, M. Paciorek, op. cit., s. 85; D. Lizun, Problematyka konserwacji ottarza gtómnego z kościoła p.w. Wniebowziecia NMP w Kiełbasinie, „Biuletyn Informacyjny Konserwatorów Dzieł Sztuki”, nr 3-4, 2004, s. 135; M. Malska, Ikona Matki Boskiej z. Diieciatkiem, „Biuletyn Informacyjny Konserwatorów Dzieł Sztuki” 2001, nr 1, s. 10; E. Marxen-Wolska, Konserwacja podobraz̨i drewnianych $i$ warstw malarskich çterech obrazón zamoczonych w czasie powodzi we Florencji, Konserwacja malarstwa sztalugowego, „Biblioteka Muzealnictwa i Ochrony Zabytków” 1970, seria B, t. 27, s. 70; J. Rudkowski, Sesja..., s. 79; M. Szuster-Gawłowska, Konserwacja obrazu z.przedstawieniem „Matki Boskiej z. Drieciatkiem” typu „Piekarskiego” ₹ Pustelnika, „Ochrona Zabytków” 1986, nr 3, s. 181; E. Steffny, Bergung, Konservierung und Montage der konstantinischen Deckenmalerei aus dem Prunksaal unter Trierer Dom, „Arbeitsbläter für Restauratoren” 1986, nr 2, s. 113119. Podaję na podstawie informacji zawartych na http://www.bcin.ca (dostęp 2005.01.05); S. Stepień, B. Czajkowska-Palusińska, Konserwacja polichromowanych desek stropowych z kościoła w Haczowie oraz aranżaja stropu nawy z. właczeniem zachowanych gotyckich desek, „Biuletyn Informacyjny Konserwatorów Dzieł Sztuki” 2003, nr 3-4, s. 81; M. E. Viana, A panel transfer problem, [w:] Conservation of Wood in Painting and the Decorative Arts, Preprints of the Contributions to the Oxford Congress, 17-23 September1978, London 1978, s. 181-182; D. Wierzbicka, Konserwacja obrazu Matka Boska ₹. Drieciatkiem ₹. kościoła parafialnego we Wrocimowicach, [w:] Studia i Materialy Wydziatu Konserwacji $i$ Restauracji Dz̧iet Sztuki Akademii Sztuk. Pięknych w Krakowie, t. VIII: Nowe pokolenie konserwatorów krakowskich, Kraków 1998, s. 67.

${ }^{136}$ K. Broschke, J. Freitag, C. Meckel, Ch. Zitzmann, H. Beckert, Eine Gartenkalesche Friedrichs des Großen. Materialkombination: teilweise polychromiertes Hol₹, Metall, Leder und Textil, 
Właściwościami podobnymi do Paraloidu B-72 cechuje się Paraloid B-82, będący kopolimerem akrylanu etylu z metakrylanem metylu. Jest to żywica bezbarwna, przezroczysta, termoplastyczna, o temperaturze zeszklenia $35^{\circ} \mathrm{C}$, twarda i elastyczna (bardziej niż Paraloid B-72). Dobrze rozpuszcza się w rozpuszczalnikach organicznych, ponadto cechuje go właściwość rozpuszczania się w niektórych mieszaninach alkohol-woda. Jest odporny na wodę, chemikalia i atak mikroorganizmów. Podobnie jak Paraloid B-72 można go zakwalifikować do żywic o najwyższej odporności na działanie ultrafioletu i podwyższonej temperatury. Żywica ta nie wykazuje zmian w czasie, nie żółknie, nie traci elastyczności, pozostaje rozpuszczalna ${ }^{137}$.

Kolejno, wymienić należy, jako przynależny do grupy Paraloidów, Paraloid B-48N, będacy kopolimerem metakrylanu metylu i akrylanu butylu ${ }^{138}$. Żywica ta zasadniczo nie jest wykorzystywana do impregnacji wzmacniającej drewna.

\section{Wnioski}

Przedstawiony przegląd materiałów syntetycznych wyraźnie pokazuje różnorodność środków stosowanych w zabiegach impregnacji wzmacniającej zniszczone drewno obiektów zabytkowych. Część z nich, już niestosowana, wydaje się z obecnego punktu widzenia nieodpowiednia do celów, w jakich zostały wykorzystane. Świadomość ich właściwości i ewentualnego szkodliwego oddziaływania na obiekty jest nieodzowna, gdyż są one już na trwałe wbudowane w strukturę zabytków.

„Restauro” 1998, nr 5, s. 332; O. Coprara, Conservation Work on fifteenth century wood intarsia in the Old Sacristy of Florence Cathedral, [w:] Conservation of Wood in Painting and the Decorative Arts, s. 67; V. von Reventlow, Use of B 72 in the restoration of marquetry surface - case history, [w:] Conservation of Wood in Painting and the Decorative Arts, Preprints of the Contributions to the Oxford Congress, s. 37-38.

137 J. Jakubiak, M. Nowakowska, op.cit., s. 31-32; V. Kyzelyté, op.cit., s. 63.

138 V. Kyzelytė, op.cit., s. 64. 


\section{Summary}

Historically used consolidants for strengthening impregnation treatment of damaged, polychrome, antique wood - preliminary survey. Part II: Materials based on synthetic constituents

This paper deals with the number of materials, based on synthetic constituents, used for strengthening impregnation treatment of antique, wooden objects since about fifties of $20^{\text {th }}$ century. To this group belong: paraffin wax, microcrystalline wax, amino resins, polymers derived from cellulose, urea resins, cycloheksanone polymers, polystyrene and polyester resins, formaldehyde resins, vinyl polymers, epoxy resins and acrylic resins.

The reader is introduced with their properties, lying stress on drawbacks, negative aspects and harmful effects of their applications to wood, polychromy and gilding. 